\title{
29. SEISMIC STRATIGRAPHY OF CENOZOIC SEDIMENTS FROM NORTH PACIFIC SEAMOUNT PLATFORM AND DEEP-SEA SITES, LEG 145
}

\author{
T.S. Hamilton ${ }^{2}$
}

\begin{abstract}
High-resolution, digital, single-channel seismic profiles collected aboard the JOIDES Resolution provide a regional stratigraphic context for seven drill sites (881-887) from four locations in the North Pacific. The seismic thickness of the sedimentary section varied from $>1$-second two-way traveltime at the Detroit Seamount in the northern Emperor Seamount Chain to $<0.1 \mathrm{~s}$ TWT at the abyssal seafloor Sites $885 / 886$ near the Chinook Trough. The 1-ms data were processed with SIOSEIS receiving mute, deconvolution, gain recovery, and time-varying filters to enhance reflections and correlate to synthetic seismograms generated from downhole logs and physical properties data. The reflection sequence at each site was correlated to the lithostratigraphy and impedance contrasts caused by density and velocity variations with an average mistie of about $3 \mathrm{~m}$ over several hundred meters. A three-part seismic character was recognized at all locations. The uppermost glacial- and ash-influenced Pliocene-Pleistocene section had high frequencies and spatial variability characteristic of enhanced hemipelagic sedimentation. Miocene diatom oozes dominate the draping and acoustically transparent middle section. Alternating intervals with discontinuous high-frequency reflections and more widely correlated moderate-amplitude reflections appear as the high cut and gain are increased. These correspond to alternating intervals of greater and lesser variability in the physical properties. The basal sedimentary section tends to be Paleogene and is characterized by moderate to strong reflections that lap and dip with respect to local basement relief and show evidence of bottom-current influence and downslope slumping and reworking. These near-basement lithologies include claystone, chalk, altered ash, and sediment-sill complexes.

The seismic stratigraphy at Site 881 on the Zenkevich Rise has folds, unconformities, and faults that cut to the top of the section and show tectonic reactivation on the approach to the Kurile Trench. High-latitude seamount platforms like those sampled at the Detroit Seamount sites (882-884) and at Site 887 on the Murray Seamount show great thicknesses and fast rates of middle Tertiary sedimentation. From the high-resolution seismic stratigraphy, the middle Tertiary biosiliceous ooze offers the best prospect for investigations of paleoclimatic and oceanography cyclicity.
\end{abstract}

\section{INTRODUCTION}

This paper presents selected seismic data acquired aboard the JOIDES Resolution during the site occupancy surveys of Ocean Drilling Program (ODP) Leg 145 (North Pacific transect) (Fig. 1). Line ends, lengths, and survey speeds are given along with well projections to the nearest shotpoint in survey tables and location figures for each site. Most surveys duplicated a portion of the record used to select the drill site and crossed back over the site in the shape of a normal or inverted numeral 4. Navigation was by global positioning system (GPS).

Digital single-channel seismic data was acquired where possible using an 80 - and a 200 -in. ${ }^{3}$ water gun ${ }^{3}$ fired simultaneously into a single-channel, Teledyne hydrophone array. ${ }^{4}$ Array placement varied somewhat from survey to survey so offset corrections are given separately for each site. Nominal 10 -s records were recorded at firing rates of $11 \mathrm{~s}$ in SEG-Y format on 9-track tape. Digitization rates varied from survey to survey (either 2,1 , or $0.5 \mathrm{~ms}$ ) depending on the

'Rea, D.K., Basov, I.A., Scholl, D.W., and Allan, J.F. (Eds.), 1995. Proc. ODP, Sci. Results, 145: College Station, TX (Ocean Drilling Program).

2Pacific Geoscience Centre, Geological Survey of Canada, P.O. Box 6000, Sidney, BC V8L 4B2, Canada.

${ }^{3}$ The seismic sources consisted of Seismic Sources Inc. T water gun S80 Model 03 and a Hamco Instrument and Machine HW-200 water gun.

4Teledyne Model 178 Custom Hydrostreamer, consisting of 60 model T-1 hydrophones in a single active grouping $88 \mathrm{~m}$ long with an interelement distance of $1.49 \mathrm{~m}$. The elements are all equally weighted and there is no taper to the array. thickness and depth of the sedimentary section. Other instrumentation included $3.5-$ and $12-\mathrm{kHz}$ sub-bottom profilers, recorded as ana$\log$ records, and a towed magnetometer.

All seismic records were processed on board using a UNIX-based version of the SIOSEIS processing software and Masscomp computers. The objective of the processing was to enhance high-resolution stratigraphy and remove interbed multiples. The processing sequence typically included mute to water bottom, time-varying filters that usually ranged from 50 to $150 \mathrm{~Hz}$ and ramped where significant dips occurred, mild automatic gain control (AGC) with long design windows, and spiking deconvolution using short design windows selected from the data. Extensive testing of time-varying filters and deconvolution parameters resulted in the versions of the lines shown. Detailed processing sequence information and values of SIOSEIS processing parameters are given in Table 1.

This paper consists of a site-by-site discussion of the seismic data and the detailed correlation to the stratigraphy. The correlation was achieved using the physical properties (velocity and density) data given in Rea, Basov, Janecek, Palmer-Julson, et al. (1993) to construct impedance traces and synthetic seismograms. Detailed assignment of reflections depends on velocity and density depth functions which occasionally correspond to lithologic variations. Interpretations of the seismic stratigraphy are presented to provide a regional context for the lithostratigraphy, its seismic facies and sense of lap, its variation away from the site, and the significance of each stratigraphic unit and its sedimentation rates. Occasionally, seismic facies suggest that changes in depositional style do not coincide with the original lithostratigraphic subdivision given in Rea, Basov, Janecek, 


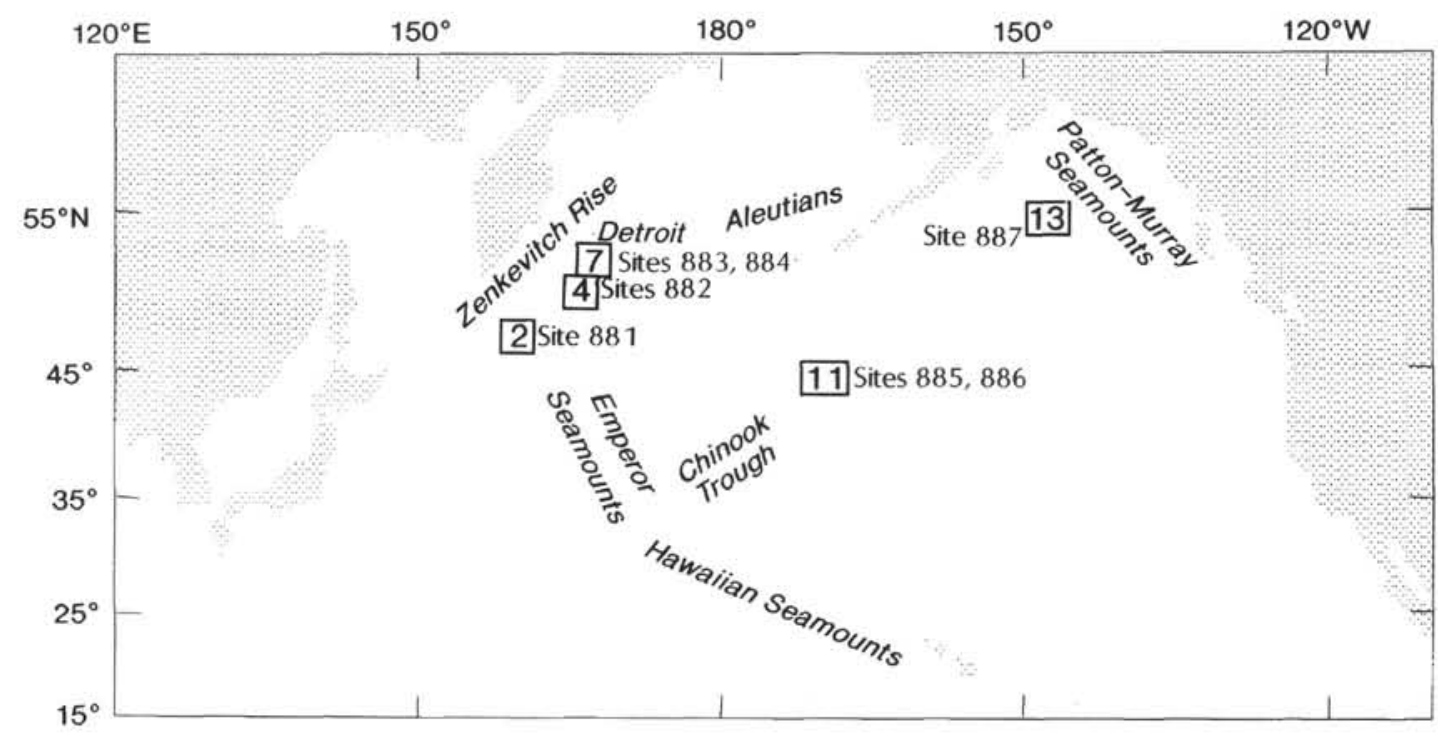

Figure 1. Index to the location of seismic survey figures (figure numbers indicated in boxes) and sites occupied during Leg 145. Prominent geographic features are labeled for reference.

Table 1. SIOSEIS processing parameters for Leg 145 seismic data.

Yo-1a: 2 ms, MUTE, AVENOR, DECON, FILTER, MIX, AGC

DECON: SEDTS $-0.0,-0.2$; SEATS $-0.0,-0.2$; FILLEN 0.201 ; PREWHI 15

FILTER: $\quad(-0.0,-0.5) \quad(25-200 \mathrm{~Hz})$

MIX 161, AGC Winlen 0.350, $\stackrel{(-0.7,-1.5)}{\text { STIME } 6.9 \mathrm{~s}}$

$(25-55 \mathrm{~Hz})$

De-2a: $1 \mathrm{~ms}$, MUTE, WBT, WEIGHT, DECON, FILTER, AVENOR, AGC, MIX

FILTER:

$$
\begin{array}{lll}
(0.0,4.15) & (25-50 \mathrm{~Hz}) & \text { LEN } 51 \\
(4.30,5.25) & (25-500 \mathrm{~Hz}) & \text { LEN } 151
\end{array}
$$$$
(4.30,5.25) \quad(25-500 \mathrm{~Hz}) \text { LEN } 151
$$

DECON: SEDTS $-0.0,-0.25$; PREWHI 15 ; LEN 0.201

MIX: 161 , STIME $4.0 \mathrm{~s}$

De-34a: I ms, WBT, MUTE, DECON. FILTER, AVENOR, AGC, MIX

3 FILTERS: $\quad(0.0,0.43) \quad(25-140 \mathrm{~Hz})$ LEN $155 \quad(0.0,0.495)$

$\begin{array}{lllll}\text { Ramped } & (0.0,0.43) & (25-140 \mathrm{~Hz}) & \text { LEN } 155 & (0.0,0.495) \\ \text { Rat } & (0.55,0.755) & (25-100 \mathrm{~Hz}) & \text { LEN } 155 & (0.62,0.82)\end{array}$

$\begin{array}{lcccc}\text { Ramped } & (0.55,0.755) & (25-100 \mathrm{~Hz}) & \text { LEN 155 } & (0.62,0.82) \\ \text { Down and across } & (0.86,1.43) & (25-45 \mathrm{~Hz}) & \text { LEN 325 } & (0.925,1.358)\end{array}$

DECON: SEDTS $-0.0,-0.25$; PREWHI 15 ; LEN 0.201

MIX: 13831, STIME $3.1 \mathrm{~s}$

De-4a: I ms, WBT, MUTE, DECON, FILTER, AVENOR, AGC, MIX

$\begin{array}{lllll}4 \text { FILTERS: } & (0.0,0.138) & (25-150 \mathrm{~Hz}) & \text { LEN 151 } & (0.0,0.18) \\ \text { Ramped } & (0.32,0.41) & (25-130 \mathrm{~Hz}) & \text { LEN 131 } & (0.34,0.43)\end{array}$

$\begin{array}{lcccc}\text { Ramped } & (0.32,0.41) & (25-130 \mathrm{~Hz}) & \text { LEN 131 } & (0.34,0.43) \\ \text { Down and across } & (0.54,0.63) & (25-55 \mathrm{~Hz}) & \text { LEN 51 } & (0.55,0.7)\end{array}$

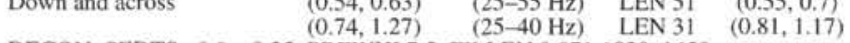

DECON: SEDTS $-0.0,-0.25$; PREWHI 7.5; FILLEN $0.071: 1020,1450$

MIX: 131, STIME $5.0 \mathrm{~s}$

De-4c: 1 ms, WBT, MUTE, DECON, FILTER, AVENOR, AGC, MIX

4FILTERS: $\quad(0.0,0.161) \quad(25-150 \mathrm{~Hz})$ LEN $155 \quad(0.0,0.146)$

Ramped $\quad(0.315,0.395) \quad(25-130 \mathrm{~Hz}) \quad$ LEN $155 \quad(0.38,0.47)$

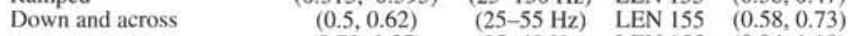

DECON: SEDTS $-0.0,-0.25 ;$ PREWHI 7.5 ; FILLEN $0.071: 1720,1932$

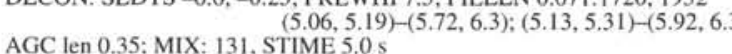

AP-5a: $1 \mathrm{~ms}$, SHIFT, WBT, MUTE, DECON. FILTER, AGC, MIX

SHIFT FFID\# $(5675-5970)+0.07 \mathrm{~s}$, FFID\#5753 0.79, etc.
FILTER: $(-0.0,-0.61) \quad(25-250 \mathrm{~Hz}) \quad$ LEN I5।

DECON: SEDTS $-0.0,-0.251$; PREWHI 7.5

AGC len 0.155; MIX: 131 , STIME 7.4 s

PM-6a: $1 \mathrm{~ms}$, SHIFT, WBT, MUTE, DECON, FILTER, AVENOR, MIX

FILTER: $(-0.1,-0.2)(25-200 \mathrm{~Hz})$ LEN 151: $(-0.3$, EOR $)(25-55)$ LEN 91

DECON: SEDTS $-0.3,-0.5$; PREWHI 7.5 ; FILLEN 0.399

MIX: 161 , STIME $4.7 \mathrm{~s}$

PM-6c: $1 \mathrm{~ms}$, MUTE, DECON, FILTER, AGC, MIX

FILTER: $(0.0-0.1,0.15,0.35,0.3)(65-200 \mathrm{~Hz})$ LEN 151 RAMPED

$(-0.205-0.98,-0.255-0.59,-0.455-0.659,-0.405-0.655)(25-55)$ LEN 9

DECON: SEDTS $-0.0,-0.45$; PREWHI $6 \%$; FILLEN 0.399

AGC: winlen 0.255 ; MIX: 121 , STIME $4.6 \mathrm{~s}$
Palmer-Julson, et al. (1993). In those cases different stratigraphic subdivisions are suggested. Suggestions are also made for future drilling targets to resolve issues raised in this study or to more completely sample the same stratigraphy. Sections are pointed out where fine-scale cyclicity in the middle Tertiary hemipelagic sedimentation manifests itself in the seismic record.

\section{RESULTS}

\section{Site 881 Seismic Survey Parameters}

This site is located in the northwest Pacific on the Zenkevich Rise, between the Kurile Trench and the Emperor Seamount Chain (Fig. 2). A total of $54.4 \mathrm{~km}$ of single-channel digital water-gun data was collected in three profiles for Site 881 (Table 2) in the shape of the numeral 4 on 20 July 1992 immediately before occupying the drill site. With $457 \mathrm{~m}$ of tow cable used for the streamer deployment, the depth point for the seismic trace is $337 \mathrm{~m}$ behind the fix and $378 \mathrm{~m}$ behind the high-resolution sub-bottom profiles. Line Yo-1a, $30.7 \mathrm{~km}$ long (Table 2; Figs. 2,3), failed to duplicate a portion of the prefatory survey Line VEMA-2110 (08/27/65 0230-0500 hr), presumably because of navigational inaccuracies in the older data. The site location, on the predetermined coordinates, was somewhat off of the site-survey profiles as indicated for the projected ties (Table 2). The site was situated adjacent to a Neogene fault within a local graben. While the processed seismic records are of reasonable quality, reflections are discontinuous, and are particularly poorly resolved in the vicinity of the site. As a result of this, and of the offset between the drill site and the survey lines, the tie to the seismic survey is poor for this site.

\section{Site 881 Seismic Stratigraphic Correlation}

A portion of the seismic Line Yo-la (Fig. 3) over the site shows approximately $0.5 \mathrm{~s}$ two-way traveltime (s TWT) above the basement reflection, for a local sedimentary thickness of $385 \mathrm{~m}$. The seafloor reflection occurs at $7.342 \mathrm{~s}$ TWT, with a strong coherent side lobe or bottom-simulating reflector (BSR) $40 \mathrm{~ms}$ later. Shallower than 142 $\mathrm{ms}$ bsf, the section is reflective but laterally incoherent. The first prominent sub-bottom reflection occurs at $7.492 \mathrm{~s}$ TWT, corresponding to $142 \mathrm{~ms}$ bsf and a depth of about $113 \mathrm{mbsf}$. The 142-ms reflec- 

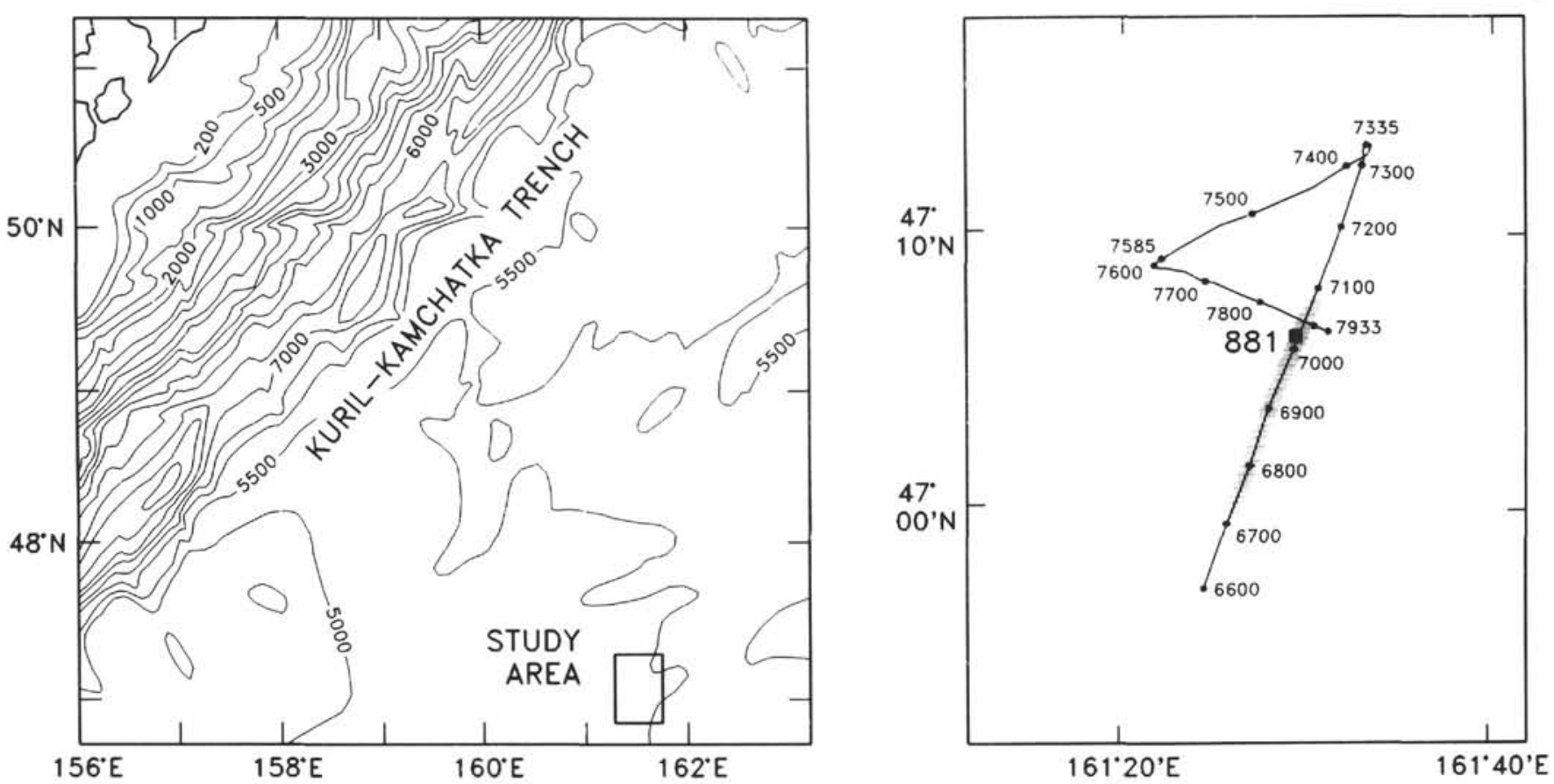

Figure 2. Regional bathymetric setting (left) and location of site occupancy survey for Site 881 (right). Bathymetry after GEBCO Chart 5.02 (Udintsev, 1984). Shotpoint numbers are annotated with time ties provided in Table 2. Shading indicates the portion of the seismic profile shown in Figure 3.

Table 2. Location parameters for seismic survey of Site 881 .

\begin{tabular}{clccccc}
\hline Site & Line & Day & Time & Shot & Latitude (N) & Longitude (E) \\
\hline \multirow{2}{*}{881} & Yo-1a & 210 & 1200 & 6599 & $46^{\circ} 56.889^{\prime}$ & $161^{\circ} 24.648^{\prime}$ \\
& EOL & & 1442 & 7335 & $47^{\circ} 12.444^{\prime}$ & $161^{\circ} 32.888^{\prime}$ \\
881 & TIE & & 1336 & 6821 & \pm 5 shots & $198 \mathrm{~m} \mathrm{NW}$ \\
& Yo-1b & & 1442 & 7335 & $47^{\circ} 12.444^{\prime}$ & $161^{\circ} 32.888^{\prime}$ \\
& EOL & & 1622 & 7585 & $47^{\circ} 09.188^{\prime}$ & $161^{\circ} 23.251^{\prime}$ \\
& Yo-1c & & 1622 & 7585 & $47^{\circ} 09.188^{\prime}$ & $161^{\circ} 23.251^{\prime}$ \\
& EOL & & 1741 & 7933 & $47^{\circ} 06.845^{\prime}$ & $161^{\circ} 30.510^{\prime}$ \\
881 & TIE & 210 & 1726 & 7886 & $1.464 \mathrm{~km}$ & Due south \\
\hline
\end{tabular}

\begin{tabular}{ccccccc}
\hline Line & $\begin{array}{c}\text { Length } \\
(\mathrm{m})\end{array}$ & Shot & $\begin{array}{c}\text { Time } \\
(\mathrm{min})\end{array}$ & $\begin{array}{c}\text { Seconds/ } \\
\text { shot }\end{array}$ & $\begin{array}{c}\text { Meters/ } \\
\text { shot }\end{array}$ & $\begin{array}{c}\text { Kilometers/ } \\
\mathrm{hr}\end{array}$ \\
\hline -1a & 30,651 & 736 & 162 & 13.0 & 41.6 & 11.4 \\
-1b & 13,587 & 250 & 100 & 24.0 & 54.3 & 8.17 \\
-1c & 10,153 & 348 & 79 & 13.6 & 29.2 & 7.71 \\
\hline
\end{tabular}

tion occurs at a velocity increase and lithologic contrast to the increasing clay and ash content below the reflection horizon. The section from 0 to $142 \mathrm{~ms}$ bsf (Subunit IA) is double the regional thickness, wherein the increased thickness is restricted to a channel or graben of about $2 \mathrm{~km}$ width on the south-southwest side of the fault at shotpoint 6558 . The base of a local channel fill and the uppermost of a series of folded reflections of regional significance occur between 7.544 and $7.568 \mathrm{~s}$ (194 and $218 \mathrm{~ms}$ bsf), corresponding to a 20$\mathrm{m}$-thick transitional zone at the top of lithologic Subunit IB (155-175 mbsf).

The folded high-frequency reflection sequence associated with Subunit IB corresponds to an interval of increasing velocity and decreasing density, with the lithologic transition to increasing diatom content and ash count below. The character of the reflections at the top of Subunit IB is laterally variable (implying the transitional interval is variable also), the horizon can be correlated regionally, despite its thinning to the south-southwest.

The underlying sedimentary succession to basement has a nearly constant thickness of about $220 \mathrm{~m}$. The remainder of the sedimentary succession penetrated is reflective but still not very coherent, with a few low-frequency and low-amplitude reflections that drape basement relief. Two of these draping reflections can be correlated to the cores. The upper one occurs at $7.656 \mathrm{~s}$ ( $306 \mathrm{~ms}$ bsf and $248 \mathrm{mbsf}$ ), below which density, velocity, and clay content all increase. The lowermost reflection penetrated by the well occurs at $7.701 \mathrm{~s}(351 \mathrm{~ms}$ bsf and $270 \mathrm{mbsf}$ ) at a density decrease corresponding to the top of another section of diatomite. Below the maximum depth of penetration there is an $80 \mathrm{~ms}$ unreflective interval with two strong coherent reflections in the $50 \mathrm{~ms}$ above the basement.

\section{Site 881 Seismic Interpretation}

Site 881 (Fig. 3) is situated adjacent to a Neogene fault that bounds a local graben. The decreasing offset of reflections upsection resembles growth faulting. The site is situated at the foot of a fault scarp approximately $800 \mathrm{~m}$ from the projected fault outcrop. The location of holes $(881 \mathrm{~A}, 881 \mathrm{~B}$, and $881 \mathrm{C})$ near a fault causes shortscale facies changes and correlation disparities between holes. Because of the setting for this site, the regional significance of sedimentation rates, particularly for the upper unit, should be restricted. The reflections of greatest lateral extent coincide with transitions in physical properties and lithology. Were the seismic section to provide the rule for breaks in the sedimentation curve, these would occur at 113, 165, 248, and 270 mbsf. Seismic Line Yo-la (Fig. 3) shows that the $160 \mathrm{~ms}$ greater sediment thickness on the downthrown block occurs in the Pliocene-Pleistocene section of the drill hole.

On the site-survey seismic lines, the folding that affects everything downsection from Subunit IB reveals up to $550 \mathrm{~m}$ of closure over a distance of $15.3 \mathrm{~km}$, for apparent dips of $4.1^{\circ}$ (e.g., to the southwest Line Yo-1b; not shown). The episode of folding and faulting that affects this site is possibly related to deformation induced as this segment of seafloor approached the Zenkevich Rise (outer bulge of the Kurile Trench). Seismic stratigraphy suggests that the significance of this site is the local enhancement in the uppermost section which is preserved in a graben. The tectonic reactivation at this site provides a natural amplifier that expands the Pliocene-Pleistocene 


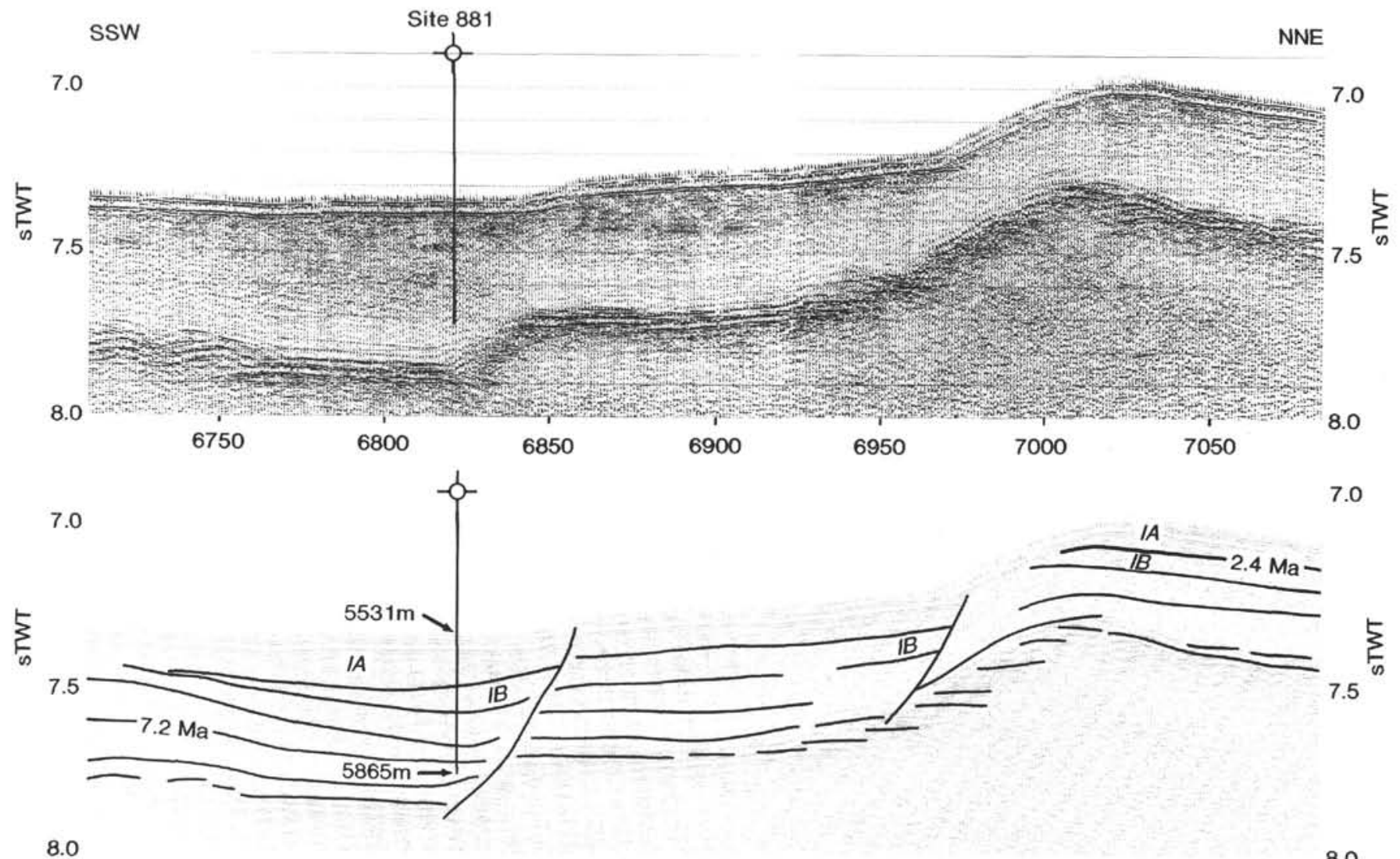

V.E.x6.25

$\widetilde{500 m}$

Figure 3. Processed, digital, single-channel seismic Profile YO-1a through Site 881 near the Kurile-Zenkevich Rise. Location information is given in Figure 2 and Table 2. On this and subsequent seismic profiles, the interpretation is presented on a screened-back version of the processed line shown above. The bold black line indicates the site location in a local trough. Depth below sea level of the seafloor and maximum depth of penetration are shown. V.E. denotes vertical exaggeration, assuming a seawater velocity of $1500 \mathrm{~m} / \mathrm{s}$. For this and subsequent sections, traces are labeled with their field file identification number (FFID), but for convention these are called shotpoints throughout the text. Processing routines in sequence were MUTE, AVENOR, DECON, FILTER, MIX, and AGC, using the parameters listed in Table 1. Lithostratigraphic units and ages are from Rea, Basov, Janecek, Palmer-Julson, et al. (1993).

stratigraphy. Similar sites could be sought along this part of the northwest Pacific-Asian margin to provide other high-resolution records for the past few million years.

The sedimentary reflectors have a pronounced directional anisotropy in their coherence and lateral correlation. The greatest continuity is in a northwest-southeast direction, which is parallel to the axis of a tongue of sediment extending this direction from the vicinity of the Russian Margin (Ludwig and Houtz, 1979; Jacobi and Hayes, 1989) near $53.5^{\circ} \mathrm{N}, 163^{\circ} \mathrm{E}$. This southeast-directed tongue of sediment at about $0.4 \mathrm{~s}$ thickness on the southwest side of the Obruchev Rise is probably analogous to the thicker and more extensive Meiji Drift (Scholl et al., 1977) sampled at Site 884 farther to the east.

The seismic stratigraphy and correlation to the site show three items of regional significance. First, Subunit IB samples approximately the upper half of a hemipelagic unit of diatom ooze that constitutes the bulk of the sedimentary succession between the Emperor Rise and the Russian Margin. Second, this unit is folded, faulted, and overlain by an unconformity that is younger than $2.6 \mathrm{Ma}$. Above this, the clayey diatom ooze of Subunit IA is highly variable in thickness and facies. Finally, the site position records an unusually thick succession for this subunit as a channel or graben infilling. Sedimentation rates for this uppermost facies are probably maxima for this part of the northwest Pacific.

\section{Site 882 Seismic Survey Parameters}

This survey crossed the southernmost of a pair of sites near Wayne and Detroit seamounts on the northern portion of the Emperor Seamount chain. The survey for Site 882 collected $27.3 \mathrm{~km}$ of singlechannel water-gun data as one long line $(17.6 \mathrm{~km})$ and two short lines in the shape of a backward numeral 4 (Table 3; Fig. 4). With $488 \mathrm{~m}$ of tow leader, the offset for the seismic trace is $352 \mathrm{~m}$ behind the GPS fix, and $393 \mathrm{~m}$ behind the high-resolution sounders. Line De-2a (Fig. 5) began with a $2-\mathrm{ms}$ sampling rate and switched to $1-\mathrm{ms}$ rate during the line. Line De-2a duplicates a portion of record collected on 13 August 1988 by the Thomas Washington. Poor resolution of reflections was noted on Line De-2a during the approach to Site 882, therefore, at $0340 \mathrm{hr}$ and shotpoint 2028 , the streamer was changed and found to contain air in the leader. The processed record (Fig. 5) shows a phase change at this point, particularly for the reflections at midsection, which is caused by the different responses in the two streamers and is an artifact of acquisition, not of processing or geology. The use of two water guns produced an excellent high-frequency response that was better than the single 200 -in. ${ }^{3}$ water gun used on the site selection survey.

Despite some thickening and thinning of the sedimentary section related to persistent channels and basement relief, reflectors are very 
Table 3. Location parameters for seismic survey of Site $\mathbf{8 8 2}$.

\begin{tabular}{|c|c|c|c|c|c|c|c|}
\hline Site & Line & Day & Time & Shot & \multicolumn{2}{|c|}{ Latitude (N) } & Longitude (E) \\
\hline 882 & De-2a & 218 & 0254 & 1881 & \multicolumn{2}{|c|}{$\begin{array}{l}50^{\circ} 15.170^{\prime} \\
50^{\circ} 23.509^{\prime}\end{array}$} & $167^{\circ} 42.014^{\prime}$ \\
\hline 882 & $\begin{array}{l}\text { EOL } \\
\text { TIE }\end{array}$ & & $\begin{array}{l}0436 \\
0412\end{array}$ & $\begin{array}{l}2503 \\
2153\end{array}$ & \multicolumn{2}{|c|}{ \pm 7 shots } & $294 \mathrm{~m} \mathrm{SW}$ \\
\hline & $\mathrm{De}-2 \mathrm{~b}$ & & 0436 & 2303 & \multirow{2}{*}{\multicolumn{2}{|c|}{$\begin{array}{l}50^{\circ} 23.509^{\prime} \\
50^{\circ} 23.298^{\prime}\end{array}$}} & $167^{\circ} 34.951^{\prime}$ \\
\hline & EOL & & 0519 & 2525 & & & $167^{\circ} 37.735^{\prime}$ \\
\hline & $\mathrm{De}-2 \mathrm{c}$ & & 0519 & 2525 & \multicolumn{2}{|c|}{$50^{\circ} 23.298^{\prime}$} & $167^{\circ} 37.735^{\prime}$ \\
\hline & EOL & & 0604 & 2752 & \multirow{2}{*}{\multicolumn{2}{|c|}{ \pm 43 shots }} & $167^{\circ} 35.847^{\prime}$ \\
\hline 882 & TIE & 218 & 0551 & 2687 & & & $1585 \mathrm{~m} \mathrm{NE}$ \\
\hline Line & $\begin{array}{l}\text { Length } \\
\text { (m) }\end{array}$ & & & $\begin{array}{l}\text { Time } \\
(\min )\end{array}$ & $\begin{array}{c}\text { Seconds/ } \\
\text { shot }\end{array}$ & $\begin{array}{c}\text { Meters/ } \\
\text { shot }\end{array}$ & $\begin{array}{c}\text { Kilometers/ } \\
\mathrm{hr}\end{array}$ \\
\hline$-2 a$ & 17,587 & & & 102 & 14.5 & 41.7 & 10.3 \\
\hline$-2 b$ & 3,322 & & & 43 & 11.6 & 15.0 & 4.64 \\
\hline$-2 \mathrm{c}$ & 6,400 & & & 45 & 11.9 & 28.2 & 8.53 \\
\hline
\end{tabular}

continuous and highly correlatable. Considerable energy and reflection continuity for reflections with frequencies higher than $140 \mathrm{~Hz}$ allows the correlation of layering on the scale of $11 \mathrm{~m}$. Thus, the seismic sections have sufficient resolution to carry picks corresponding to biostratigraphic zones or single magnetic reversals, according to data in Rea, Basov, Janecek, Palmer-Julson, et al. (1993). Specific geologic times can be assigned to reflections.

Site 882 is highly representative of the regional stratigraphy despite nearby relief (Fig. 4) and minor faulting. Within $30 \mathrm{~km}$ of Site 882 the basement displays up to $1 \mathrm{~s}(750 \mathrm{~m})$ of relief. This relief and the shallow basement elevations probably resulted from constructional seamount volcanism of the Emperor Seamount Chain. Within $10 \mathrm{~km}$ of the site the basement relief is only about $300 \mathrm{~ms}$, and most of the variation in the thickness of the sedimentary section is below $450 \mathrm{~ms}$ bsf (i.e., below the base of the hole) and related to the supertenuous drape of the underlying basement. The total sediment thickness at the site is about $1.16 \mathrm{~s}$ TWT $(1000 \mathrm{~m})$; however, the coring penetrated only the upper $580 \mathrm{~ms}$. The nearest modern abyssal channel is about $13 \mathrm{~km}$ from the site, and there is no seismic evidence that near-bottom currents influenced the upper half of the stratigraphy that was cored. Two listric faults cut the entire section on Line De-2c about 0.7 and $1.3 \mathrm{~km}$ southwest of the site. Features like this are rare, however, and do not influence the stratigraphy near the drill hole. Despite lithologic and thickness variations, most of the seismic character can be correlated among the three sites $(882,883$ and 884$)$ located near Detroit Seamount.

\section{Site 882 Seismic Stratigraphic Correlation}

Although the seismic sections contained frequency information above $285 \mathrm{~Hz}$, for correlation to the stratigraphy it was necessary to severely filter the traces to match the synthetic seismogram (Fig. 6). The downhole variation in density and velocity from the shipboard physical properties data (Rea, Basov, Janecek, Palmer-Julson, et al., 1993) was used to calculate the impedance functions and the synthetic seismogram traces for this and the other sites (Fig. 6). Although lower in frequency than the seismic profile, it contains the same basic structure, permitting a correlation to be made.

The well tie depends on the velocity/depth function, which at Site 882 has four distinct zones, each having a different, gentle linear increase of velocity with depth. Judging from the underestimation of velocities from the gamma-ray attenuation porosity evaluator (GRAPE) and physical property lab data compared to the downhole logs on the other sites (Rea, Basov, Janecek, Palmer-Julson, et al., 1993), because of core rebound expansion, these velocities, although likely to be relatively correct, are probably minimal. There is a slight progressive error with depth such that the synthetic comes in too slow (too deep). The magnitude of this velocity stretch is $1.66 \%$ over 540 $\mathrm{ms}$, which makes it noticeable but not worth correcting for, as the average velocities cannot be estimated reproducibly to that accuracy.

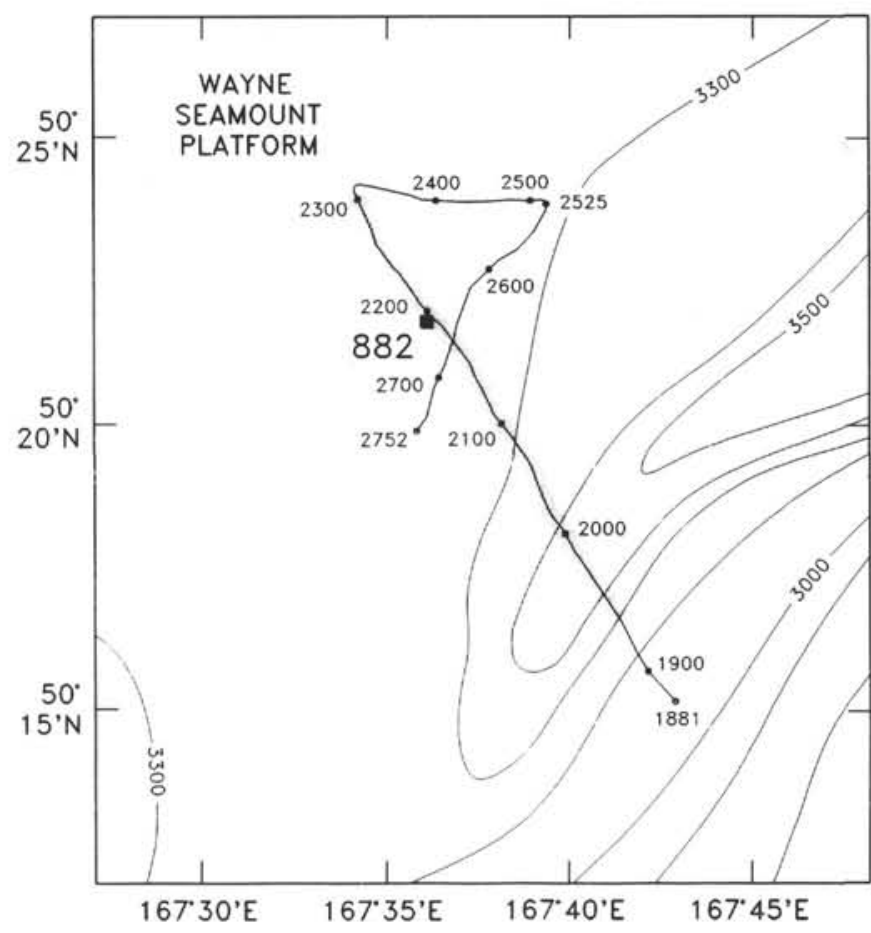

Figure 4. Regional bathymetric setting and location of site occupancy survey for Site 882 on the southeast portion of the Wayne Seamount Platform (Lonsdale et al., 1993). Bathymetry from site-selection survey data bank of the Lamont-Doherty Earth Observatory (LDEO). Shotpoint numbers are annotated with time ties provided in Table 3 . Shading corresponds to the seismic profile shown in Figure 5.

Continuous high-frequency reflections are present throughout Subunit IA, with periods of 6-20 ms, which is equivalent to $5-15 \mathrm{~m}$ of stratigraphic layering. The Subunit IA/IB boundary reflection at $4.47 \mathrm{~s}$ TWT and a depth of $100 \mathrm{mbsf}$ is generated by an abrupt decrease in density and an abrupt increase in velocity. This time horizon of $2.6 \mathrm{Ma}$ is seen as the base of the uppermost package of high-frequency reflections. An abrupt decrease in density occurs at $200 \mathrm{mbsf}$, generating a reflection at $4.6 \mathrm{~s}$ TWT that marks a time horizon of about $3.4 \mathrm{Ma}$, and the top of a relatively transparent interval containing a number of volcanic ash layers. Another decrease in the density and an inflection in the velocity function at 275 mbsf generate a reflection at $4.67 \mathrm{~s}$ TWT.

Below this point to the base of the hole, density and velocity increase monotonically, and reflections correspond to the high-frequency fluctuations in these properties. A series of intense density fluctuations between 340 and $355 \mathrm{mbsf}$ generates a series of high-frequency reflections between 4.8 and $4.85 \mathrm{~s}$ TWT. The top of this distinctive seismic marker is the 5-Ma time horizon and the lowest dropstone occurrence. The high-frequency character continues below total depth (TD) to about $4.9 \mathrm{~s}$ TWT. Below this the regionally correlated hemipelagic section extends to about $5.0 \mathrm{~s}$ TWT. Although there are numerous strong low-frequency reflections from here to basement at $5.5 \mathrm{~s}$ TWT, the thicker intervals, the lateral variation in reflection continuity, and more pronounced dips suggest a different lithology or style of sedimentation with local bottom current influence and local facies variation for this older, near-basal portion of the section.

\section{Site 882 Interpretation}

Site 882 samples the upper half of the stratigraphy of the southeast flank of the Wayne Seamount platform (Figs. 4, 5). The base of the Pliocene-Pleistocene section correlates with a strong regional reflec- 


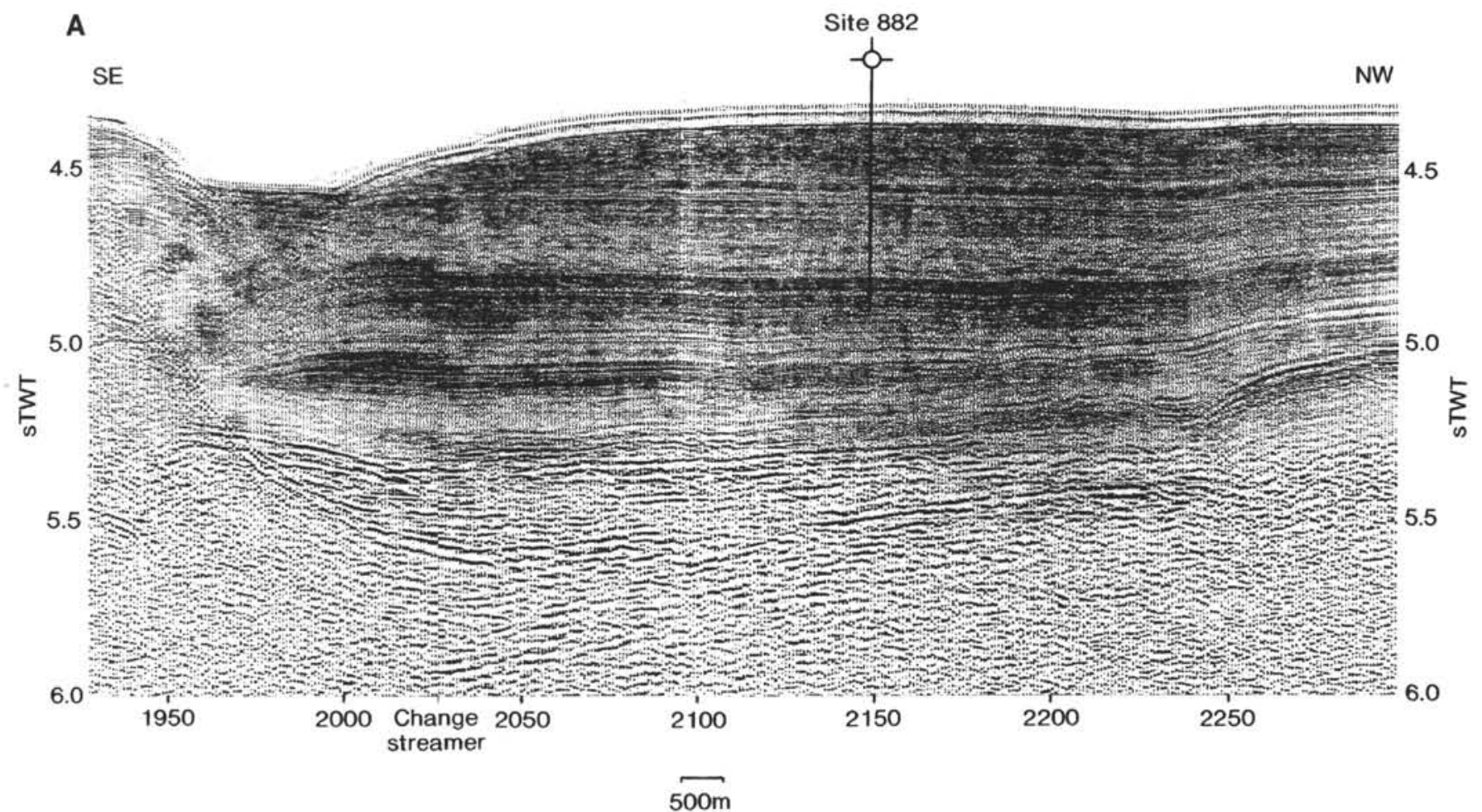

Figure 5. Processed digital, single-channel seismic Profile DE-2a through Site 882 on the flank of the Detroit Seamount in the northern Emperor Chain (A) and interpretation (B). Location information is given in Table 3 and Figure 4. The change in character seen before and after shotpoint 2028 results from changing the streamer. The bold black line indicates the site location. Depth below sea level of the seafloor and maximum depth of penetration are shown. V.E. denotes vertical exaggeration, assuming a seawater velocity of $1500 \mathrm{~m} / \mathrm{s}$. Processing routines in sequence were MUTE, WBT, WEIGHT, DECON, FILTER, AVENOR, AGC, and MIX, using the parameters listed in Table 1. Lithostratigraphic units and ages are from Rea, Basov, Janecek, Palmer-Julson, et al. (1993).

tion event. The hemipelagic section drilled is highly reflective and continuous. The fine-scale variations implied by the high-frequency reflections are all within diatom ooze, and are not caused by contrasting lithologies. The weak cyclic reflections on the seismic record (Fig. 5) and physical property (density) variations for Subunit IB at this site merit a detailed analysis for depositional cyclicity and its causes.

\section{Site 883 Seismic Survey Parameters}

Site 883 was the more northerly of a pair of sites near the Detroit Seamount on the northern portion of the Emperor Seamount Chain (Figs. 1, 7). No seismic data were recorded on the initial approach to Site 883 because of the failure of the amplifier bank in the recording lab. A single profile was shot on 19 August after Site 883 was abandoned (Table 4; Fig. 7). Line De-34a (Figs. 7, 8) passes through Site 883 on a course of $55.6^{\circ}$, at a nominal speed of $6 \mathrm{kt}(2.7 \mathrm{~m} / \mathrm{s}$ speed over ground). Using both water guns, shots averaged about $11.3 \mathrm{~s}$ $(30.7 \mathrm{~m})$ apart. The single-channel line was digitized at $1 \mathrm{~ms}$. With $488 \mathrm{~m}$ of tow leader, the offset for the seismic trace is $352 \mathrm{~m}$ behind the GPS fix, and $393 \mathrm{~m}$ behind the high-resolution sounders. The remainder of survey profile Line De-34b (Fig. 7) serves as a regional line to correlate sediment facies between those elevated on the Detroit Seamount platform (Figs. 5, 7) and their downslope equivalents of the Meiji Drift on the abyssal seafloor (see "Site 884 Seismic Survey Parameters" section, this chapter). Reflector facies appear relatively continuous at both ends of this line. Where slopes exceed $11^{\circ}$ on Line De-34b, the sediment section wedges and thins considerably (Fig. 9). For the upper $150 \mathrm{~m}$ of sub-bottom penetration, all reflections from the seafloor downward show downslope convergence.

\section{Site 883 Seismic Stratigraphic Correlation}

On Line De-34a (Fig. 8), the entire sedimentary succession to $4.147 \mathrm{~s}$ TWT ( $941 \mathrm{~ms}$ bsf and $830 \mathrm{mbsf}$ ) is reflective, with gentle dips to the northeast of $13 \mathrm{~ms} / \mathrm{km}\left(0.57^{\circ}\right)$. Individual high-frequency reflections may fade or change phase laterally over $250 \mathrm{~m}$ but packages of reflections on the order of $100 \mathrm{~ms}(75 \mathrm{~m})$ span several hundred square kilometers. Reflection sequence character at Site 883 (Fig. 8) can be correlated to Sites 882 (Fig. 5) and 884 (Fig. 10) as isochrons (time lines) rather than as lithofacies.

Unit $\mathrm{I}$ is a sequence of high-frequency reflections of variable phase and continuity that extends to $3.316 \mathrm{~s}$ TWT $(116 \mathrm{~ms}$ bsf and 87 mbsf). This upper package of reflections dips gently at less than $5 \mathrm{~m} /$ $\mathrm{km}$ and gets younger to the northeast. Basal reflections converge and downlap whereas upper reflections offlap at the seafloor. The rate of thinning is about $3.9 \mathrm{~m} / \mathrm{km}$, and this interval of clay, ashes, and dropstones thins to $66 \%$ of the thickness cored at Site 883 by the end of the profile $7.4 \mathrm{~km}$ away, which restricts the regional significance of sedimentation rates for this interval (Rea, Basov, Janecek, PalmerJulson, et al., 1993). The five reflections in this package correspond to variations in lithology, velocity, and density.

The $371 \mathrm{~m}$ of diatom and calcareous ooze of Unit II occurs between 3.316 and $3.746 \mathrm{~s}$ TWT on Line De-34a (Fig. 8). This unit is particularly apparent on the synthetic seismogram for Site 883 (Fig. 6). Unit II is weakly reflective throughout, with an upper sequence of high-frequency events that are variable in character, a middle sequence dominated by strong low-frequency events, and a basal section of high-frequency events. The sequence of high-frequency reflections comprising the upper $100 \mathrm{~ms}$ of Unit II has a flat upper surface that dips uniformly at a few meters per kilometer, but an un- 


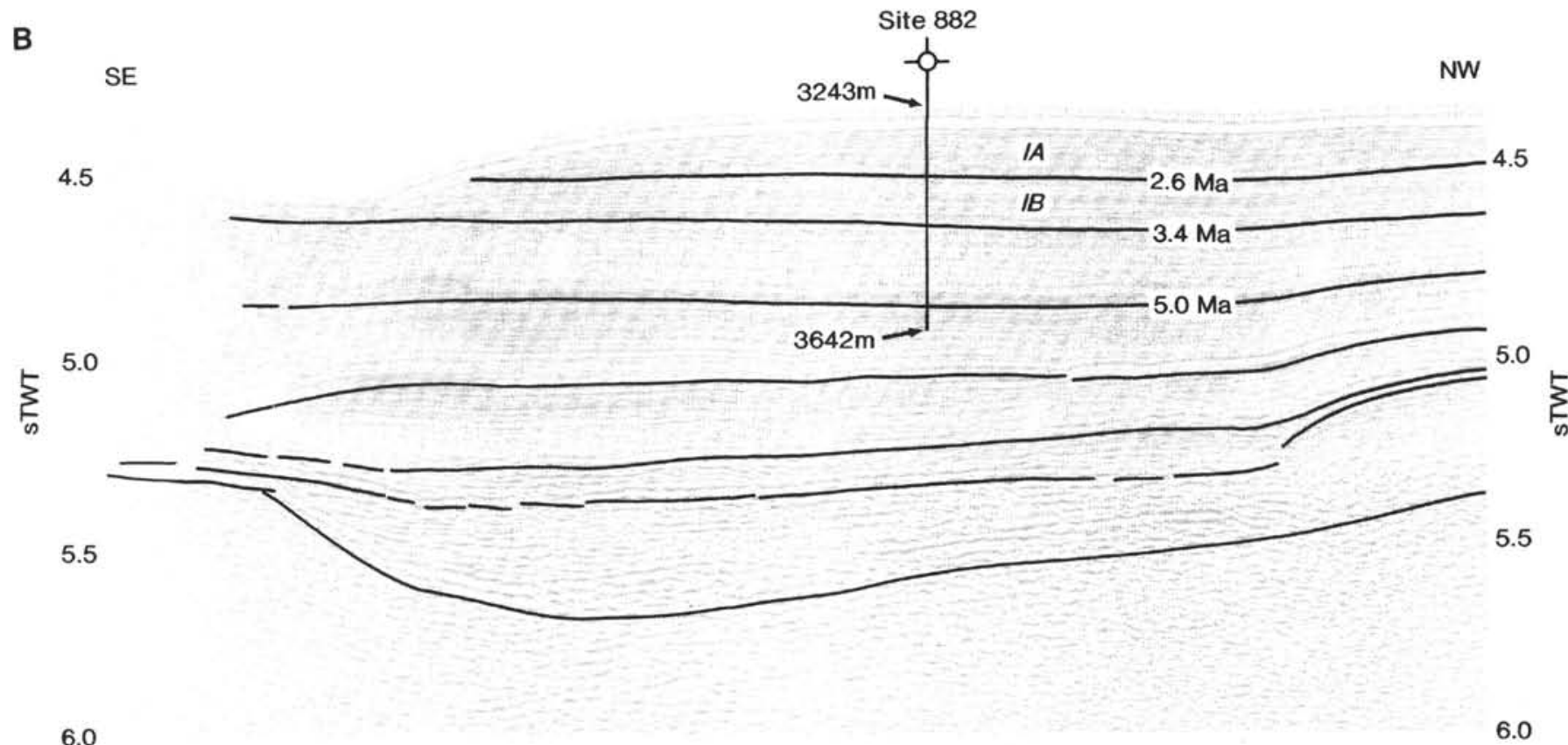

V.E.x5.56

$\widetilde{500 \mathrm{~m}}$

Figure 5 (continued).
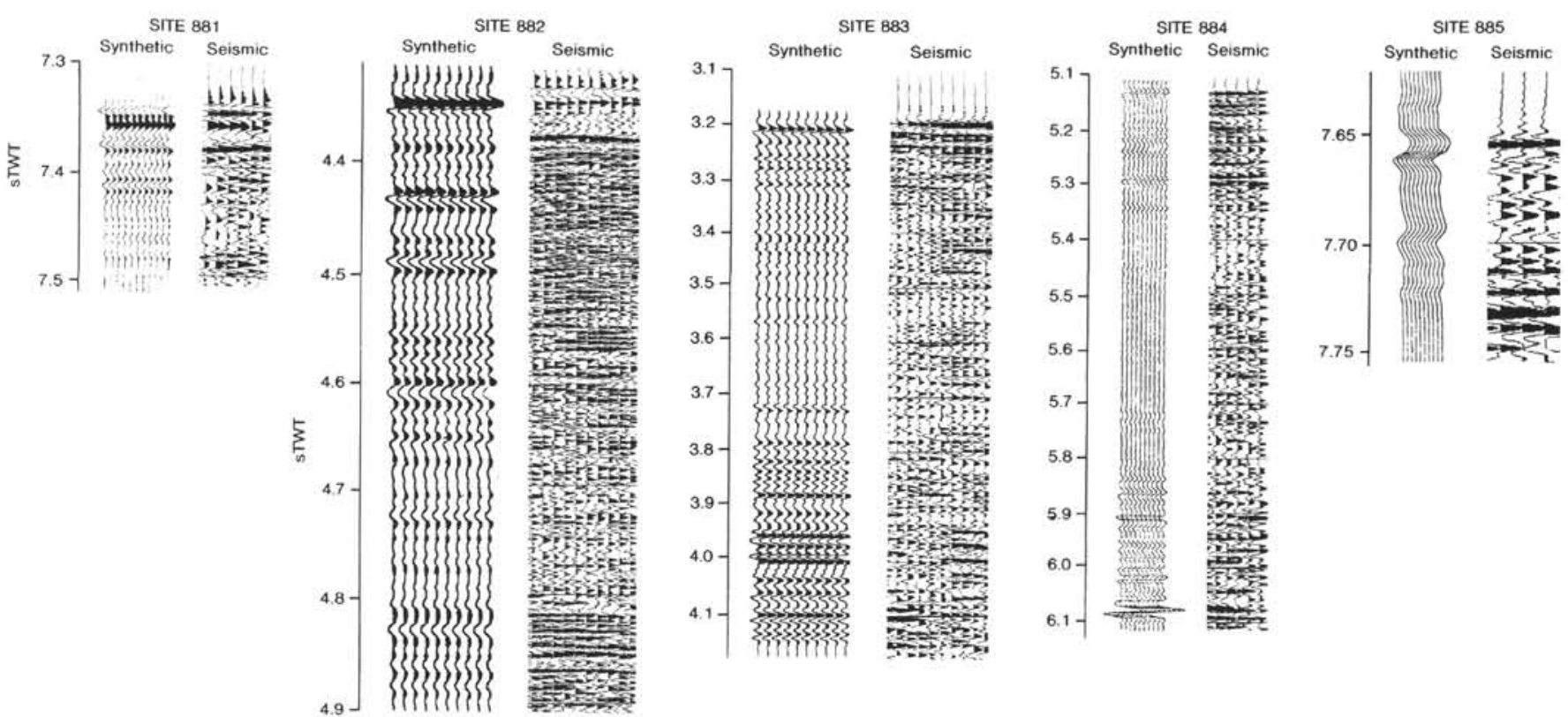

Figure 6. Synthetic seismograms and processed digital traces near well sites for Sites $881,882,883,884$, and 885 . All vertical scales are annotated in seconds two-way traveltime (s TWT) corresponding to the seismic lines shown in Figures 3, 5, 8, 10, 12, and 14. Synthetic seismograms were calculated from physical properties measurements and a source function digitized from an 80-in. ${ }^{3}$ water gun recorded on the Thomas Washington. Digital seismic traces were filtered back, and compared to the seismic profiles to match the frequency content of the synthetics.

dulating base that mirrors the drape of the underlying units, and suggests some near-bottom depositional control or reworking at around $3.4 \mathrm{~s}$ TWT or $150 \mathrm{mbsf}$. Reflections in this interval diverge as the section thickens downslope to the east-northeast.

The strongest reflection on the section occurs at about $3.415 \mathrm{~s}$ TWT, marking a 15-m-thick, high-density interval of calcareous ooze that starts at 160 mbsf. This middle section of strong low-frequency reflections in Unit II extends to about $3.555 \mathrm{~s}$ TWT $(272$ mbsf) and corresponds to alternating thick intervals of more calcareous and more diatomaceous ooze. The lowest of the three reflection packages in Unit II is characterized by a series of high-frequency reflections which exhibit lateral variations in their phase, their sense of 


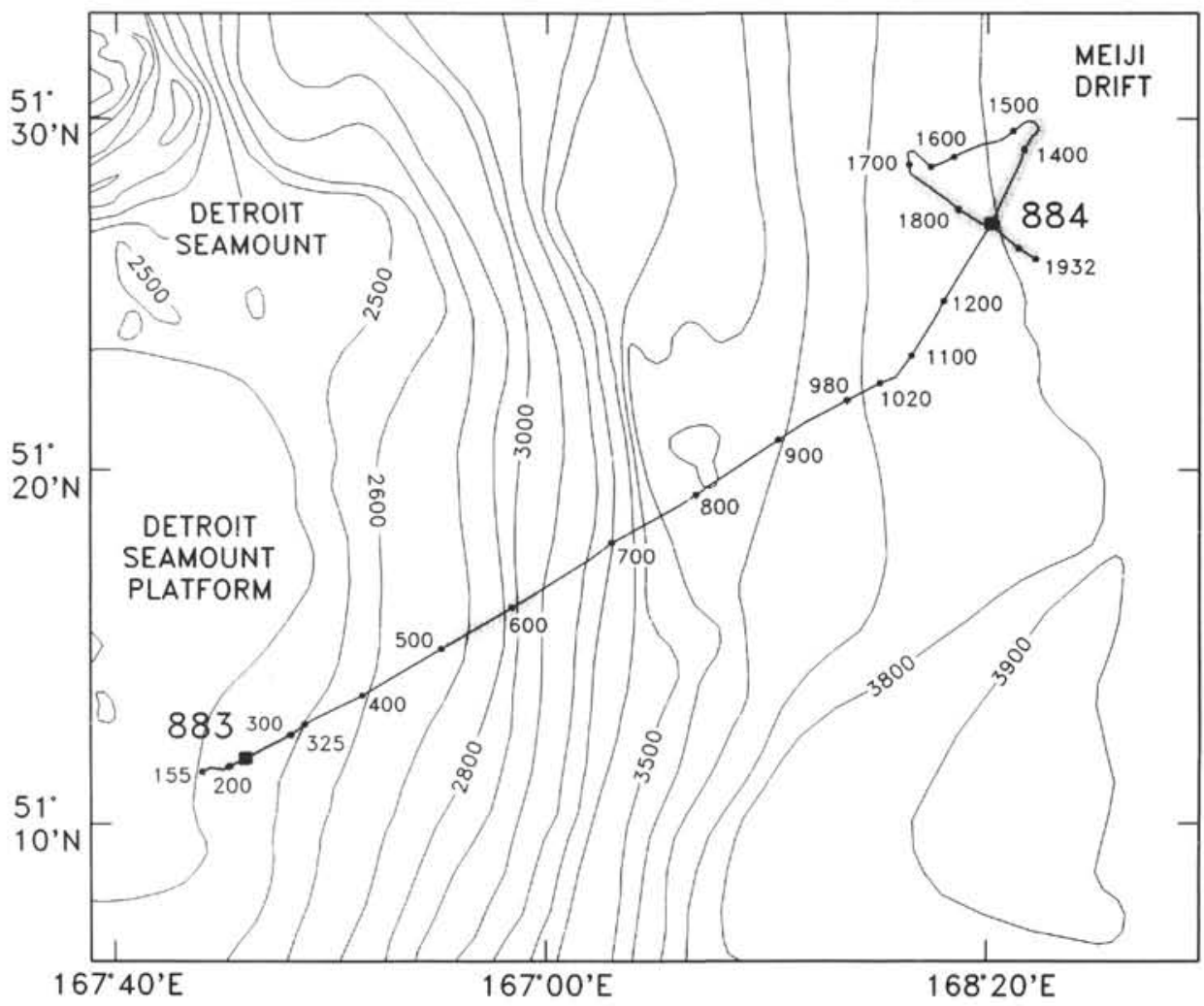

Figure 7. Regional bathymetric setting and location of site occupancy surveys for Site 883 on the east flank of the Detroit Seamount Platform (Lonsdale et al., 1993) and for Site 884 on the Meiji Drift. Bathymetry from LDEO site-selection survey data bank. Shotpoint numbers are annotated with time ties provided in Tables 4 and 5. Shading corresponds to the portions of profiles (west to east) shown in Figures 8, 9, and 10.

Table 4. Location parameters for seismic survey of Site 883.

\begin{tabular}{lllllll}
\hline Site & Line & Day & Time & Shot & Latitude (N) & Longitude (E) \\
\hline \multirow{2}{*}{883} & De-34a & 232 & 1758 & 155 & $51^{\circ} 11.645^{\prime}$ & $167^{\circ} 44.381^{\prime}$ \\
& EOL & & 1832 & 325 & $51^{\circ} 12.734^{\prime}$ & $167^{\circ} 48.514^{\prime}$ \\
883 & TIE & & 1810 & 215 & \pm 12 shots & $444 \mathrm{~m} \mathrm{SE}$ \\
& De-34b & & 1832 & 325 & $51^{\circ} 12.734^{\prime}$ & $167^{\circ} 48.514^{\prime}$ \\
883 & EOL & 232 & 2030 & 980 & $51^{\circ} 22.019^{\prime}$ & $167^{\circ} 13.361^{\prime}$ \\
\hline
\end{tabular}

\begin{tabular}{rccrccc}
\hline Line & $\begin{array}{c}\text { Length } \\
(\mathrm{m})\end{array}$ & Shot & $\begin{array}{c}\text { Time } \\
(\mathrm{min})\end{array}$ & $\begin{array}{c}\text { Seconds/ } \\
\text { shot }\end{array}$ & $\begin{array}{c}\text { Meters/ } \\
\text { shot }\end{array}$ & $\begin{array}{c}\text { Kilometers/ } \\
\text { hr }\end{array}$ \\
\hline$-34 \mathrm{a}$ & 5,220 & 170 & 34 & 12.0 & 30.7 & 9.21 \\
$-34 \mathrm{~b}$ & 44.348 & 655 & 118 & 10.8 & 67.7 & 22.5 \\
\hline
\end{tabular}

lap, and their interval thicknesses, suggesting local slumping and near-bottom current control for the lowest part of the section.

The basal section of Unit II to $3.662 \mathrm{~s}$ TWT (370 mbsf) has highfrequency reflections that change phase over about $300 \mathrm{~m}$ laterally, swell and pinch, and are replaced by two strong low-frequency events just above the Unit II/Subunit IIIA boundary at 3.757 s TWT (466 mbsf) (Fig. 8). These reflections originate from contrasts in lithology and physical properties. The sequence of reflections for Unit II here matches the character, relative thicknesses, and age of the reflections in Unit IB at Site 882.

The siliceous to calcareous transitional lithologies of Subunit IIIA correspond to the 172 -ms interval from 3.746 to 3.918 s TWT (458597 mbsf). On seismic Line De-34a (Fig. 8) this unit has two parts. The upper portion from 3.746 to $3.868 \mathrm{~s}$ TWT (458-550 mbsf) is a hemipelagic facies with evenly spaced, moderate- to high-frequency reflections that dip and thicken downslope (northeast) and show gentle drape folds. The strong reflection at $3.868 \mathrm{~s}$ TWT arises from a thick, dense interval with a higher clay content. The lower portion of Subunit IIIA is a flat-based wedge that thickens toward a source upslope to the southwest, and has short, steep internal reflections that dip and downlap to the northeast. This interval is composed of bioturbated nannofossil ooze and chalk, as described in the lithostratigraphy (Rea, Basov, Janecek, Palmer-Julson, et al., 1993). Its corresponding seismic facies has the appearance of a series of slumps, and it would be worthwhile to investigate this core interval for evidence of reworking. Because of the pronounced difference in lithology at $550 \mathrm{mbsf}$ and the complete change in depositional style seen on Line De-34a (Fig. 8) from hemipelagic above, to slump or bottom current control below, the lithostratigraphy for this interval should be redefined. Subunit IIIA should be shortened to terminate at $550 \mathrm{mbsf}$, and its base should be added to the top of underlying Subunit IIIB.

Subunit IIIB as currently defined (Rea, Basov, Janecek, PalmerJulson, et al., 1993) corresponds to the interval from 3.918 to $3.967 \mathrm{~s}$ TWT (597-652 mbsf). As with the overlying subunit, this interval has two distinctive seismic facies and depositional styles. The upper part of this subunit from 3.918 to $3.953 \mathrm{~s}$ TWT (597-636 mbsf) falls in the lower portion of, and is continuous with, the wedge of mixed nannofossil ooze and chalk described for the base of Subunit IIIA. Below $3.953 \mathrm{~s}$ TWT ( $636 \mathrm{mbsf}$ ), strong low-frequency reflections arise from density fluctuations over a zone of increasing velocity in the diatom-rich interval at the base of Unit IIIB. From the change in facies seen on the seismic Line De-34a (Fig. 8) this unit should be redefined, with a break at about $636 \mathrm{mbsf}$. Because the style of sedimentation changes at this point in the section, sedimentation rates above and below here should be reexamined.

Unit IV is not subdivided on Figure 8 because the unit is so thin. At Site 883 the boundary between Subunit IVA and IVB occurs $54 \%$ of the way down through the unit. The Subunit IVA nannofossil chalks and ashes tie to the interval from 3.967 to 4.052 s TWT (652- 


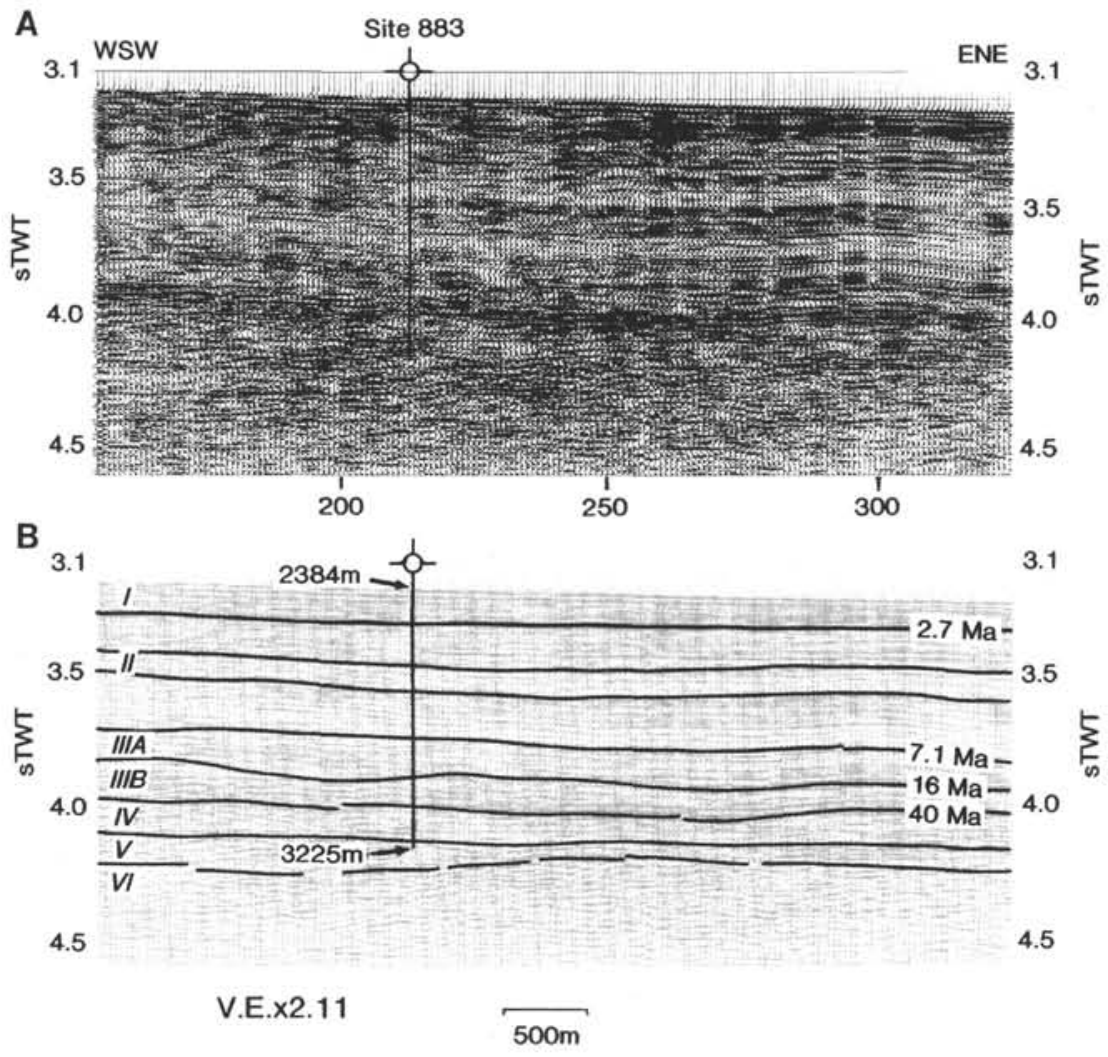

Figure 8. Processed, digital, single-channel seismic Profile DE-34a through Site 883 (A) and interpretation (B). Location information is given in Table 4 and Figure 7. The bold black line indicates the site location. Depth below sea level of the seafloor and maximum depth of penetration are shown. V.E. denotes vertical exaggeration, assuming a seawater velocity of $1500 \mathrm{~m} / \mathrm{s}$. Processing routines were MUTE, WBT, WEIGHT, DECON, FILTER, AVENOR, AGC, and MIX, using the parameters listed in Table 1. Lithostratigraphic units and ages are from Rea, Basov, Janecek, Palmer-Julson, et al. (1993).

$740 \mathrm{mbsf}$ ). This interval is a continuation of the strong low-frequency reflections found in the base of Subunit IIIB. The reflections originate from both density and velocity variations in an interval of gradually increasing velocity with depth. A seismic facies of prominent, $45-\mathrm{Hz}$ reflections with great lateral continuity encompasses chalk and diatom ooze (Subunit IIIB) and the underlying chalk and ash (Subunit IVA). These reflections are relatively flat and dip uniformly at $7 \mathrm{~ms} / \mathrm{km}$ for the length of Line De-34a (Fig. 8). The style of pelagic deposition persisted despite the change in sediment type.

The interval corresponding to Subunit IVB goes from 4.052 to 4.123 s TWT (740-814 mbsf) (Fig. 8). It has one strong continuous reflection caused by a carbonate decrease and a velocity minimum at $4.060 \mathrm{~s}$ TWT $(750 \mathrm{mbsf})$ at the base of the prominent ashes. The underlying chalk and ash are a nonreflective seismic facies of limited lateral extent.

Unit V occurs from 4.123 to $4.147 \mathrm{~s}$ TWT ( $814-830 \mathrm{mbsf}$ ) (Fig. $8)$, filling a local depression on top of the basalt that is $3.4 \mathrm{~km}$ across.

Unit VI basalts are marked by a variable amplitude reflection that occurs at $4.147 \mathrm{~s}$ TWT (below about $820 \mathrm{mbsf}$ ). Below this, strong diffractions occur to about $4.3 \mathrm{~s}$ TWT, with steep limbs that dip at 48 $\mathrm{ms} / \mathrm{km}$. The uppermost basement reflection undulates at about $20 \mathrm{~ms} /$ $\mathrm{km}$ and dips gently to the northeast at about $7 \mathrm{~ms} / \mathrm{km}$ like the overlying strong and more continuous reflections of Subunits IIIB and IVA. The amplitude of the uppermost basement reflection varies inversely with the amplitude of the overlying hard chalks, showing that their strong returns diminish the energy penetrating the underlying section.

\section{Site 883 Interpretation}

The reflection sequence for Unit II at Site 883 (Fig. 8) matches that for Subunit IB at Site 882 (Fig. 5) both in character and relative spacing. Yet the lithologies of the two sites differ. The reflection sequence similarity between these two isolated locations on the Wayne and Detroit seamount platforms extends to Site 884 on the Meiji Drift despite the wedging and thinning of the section under the intervening steep slopes as seen on Line De-34b (Fig. 9). Wherein the differences in the stratigraphy between among the three Detroit sites relate to their bathymetric isolation, steep slopes, and near-bottom transport, the persistent character seen on the reflection section at the sites must be the result of a depositional signal originating higher in the water column (surface currents, wind patterns). The detailed variation of the seismic stratigraphy and physical properties for this interval is worth investigating as a potential record of climatic or oceanographic fluctuations.

The wedge of middle Eocene through lower Miocene chalks (Subunits IVA and IIIB) is the most local feature of the stratigraphy at this site (Fig. 8), and depends on local sources and downslope reworking from the adjacent seamount. The palagonite ashes and oxides of Unit $\mathrm{V}$ are also a local feature. The remainder of the section is more regional in character.

\section{Site 884 Seismic Survey Parameters}

The survey for this site is located to the east of the Detroit Seamount on the northern portion of the Emperor Seamount Chain. The dominant geologic feature is the Meiji Drift, a thick tongue of sediment that covers this portion of the abyssal plain (Scholl et al., 1977). The survey for Site 884 collected $27.3 \mathrm{~km}$ of single-channel seismic data, as three profiles arranged like the numeral 4 rotated $34^{\circ}$ clockwise (Table 5). Seismic acquisition was a continuation of the survey for Site 883 (Fig. 7) with the exception of shot spacing, which averaged $12 \mathrm{~s}(30 \mathrm{~m})$ apart for Site 884 . The seafloor has a slight slope 


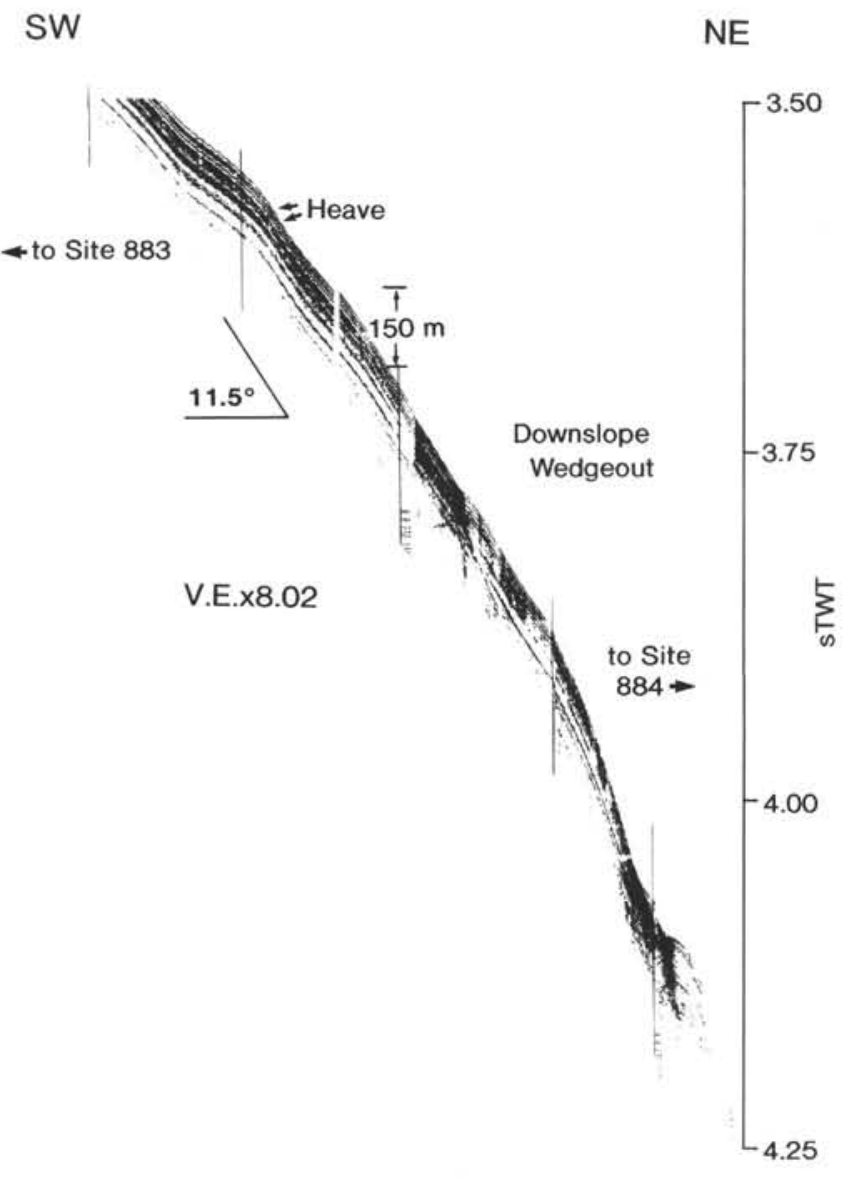

Figure 9. A portion of the $3.5-\mathrm{kHz}$ sub-bottom profile is shown for the transit down the flank of the Detroit Seamount Platform from Sites 883 to 884 , near shotpoints 500 to 600 as shown in Figure 7. The hemipelagic section pinches or deflates in a downslope direction.

Table 5. Location parameters for seismic survey of Site 884 .

\begin{tabular}{clccccc}
\hline Site & Line & Day & Time & Shot & Latitude (N) & Longitude (E) \\
\hline \multirow{2}{*}{884} & De-4a & 232 & 2038 & 1020 & $51^{\circ} 22.581^{\prime}$ & $168^{\circ} 14.428^{\prime}$ \\
& EOL & & 2204 & 1450 & $51^{\circ} 29.428^{\prime}$ & $168^{\circ} 22.128^{\prime}$ \\
884 & TIE & & 2132 & 1293 & \pm 7 shots & $122 \mathrm{~m} \mathrm{NE}$ \\
& De-4b & & 2204 & 1450 & $51^{\circ} 29.428^{\prime}$ & $168^{\circ} 22.128^{\prime}$ \\
& EOL & & 2243 & 1645 & $51^{\circ} 28.793^{\prime}$ & $168^{\circ} 18.190^{\prime}$ \\
& De-4c & & 2243 & 1645 & $51^{\circ} 28.793^{\prime}$ & $168^{\circ} 18.190^{\prime}$ \\
& EOL & 2340 & 1932 & $51^{\circ} 26.083^{\prime}$ & $168^{\circ} 22.495^{\prime}$ \\
884 & TIE & 232 & 2326 & 1858 & \pm 8 shots & $336 \mathrm{~m} \mathrm{NE}$ \\
\hline
\end{tabular}

\begin{tabular}{crccccc}
\hline Line & $\begin{array}{c}\text { Length } \\
(\mathrm{m})\end{array}$ & Shot & $\begin{array}{c}\text { Time } \\
(\mathrm{min})\end{array}$ & $\begin{array}{c}\text { Seconds/ } \\
\text { shot }\end{array}$ & $\begin{array}{c}\text { Meters/ } \\
\text { shot }\end{array}$ & $\begin{array}{c}\text { Kilometers/ } \\
\text { hr }\end{array}$ \\
\hline$-4 \mathrm{a}$ & 15,520 & 430 & 86 & 12.0 & 36.1 & 10.8 \\
$-4 \mathrm{~b}$ & 4,709 & 195 & 39 & 12.0 & 24.1 & 7.24 \\
$-4 \mathrm{c}$ & 7,080 & 287 & 57 & 11.9 & 24.7 & 7.45 \\
\hline
\end{tabular}

(about $0.45^{\circ}$ ) down to the east. Line De-4a (Fig. 10) successfully duplicates a portion of the 1987 Farnella Line 43 near $1000 \mathrm{hr}$. Figure 10 comprises portions of two seismic records: Line DE-4c passing through the site from the west-northwest and Line DE-4a leaving the site toward the north-northeast (Fig. 7).

The sea state during the site survey was very calm and the vessel attitude was steady, making ideal conditions for the high-resolution and seismic profiling. A brief discussion of the high-resolution records is significant, as it demonstrates the local nature of the seafloor apropos the deposition of the uppermost unit of clay and diatom ooze. The $12-\mathrm{kHz}$ records showed about $12 \mathrm{~m}$ of penetration, and the $3.5-\mathrm{kHz}$ record showed about $150 \mathrm{~m}$ of penetration, with resolution of reflectors on the scale of $11 \mathrm{~ms}$ or about $8 \mathrm{~m}$. On the first $3 \mathrm{~km}$ of Line De-4a (Fig. 10), the apparent slope is $0.3^{\circ}$ to the northeast and the seafloor is blocky, having local offsets of 3 to $9 \mathrm{~m}$ over $200 \mathrm{~m}$ and abundant steep diffractions. Along the final $2 \mathrm{~km}$ of Line De-4b and the first $4 \mathrm{~km}$ of Line De-4c approaching Site 884 (Fig. 7), the 12$\mathrm{kHz}$ records show a hummocky seafloor with mounds about $5.3 \mathrm{~m}$ high and $660 \mathrm{~m}$ across. The mounds sit on a regional southeast slope of $0.75^{\circ}$ and have side slopes of $0.91^{\circ}$. The site is situated in a flat, floored channel about $1 \mathrm{~km}$ across and $15 \mathrm{~m}$ deep.

The seismic records for this site resemble the pre-site-survey Farnella Line 43 in the Leg 145 site proposal, in that the upper and lower portions of the stratigraphy are highly reflective, but the middle $0.5 \mathrm{~s}$ TWT is not. This is not an artifact of acquisition or processing, but a true representation of the reflection record at Site 884. Extensive variation of seismic processing parameters for amplitude recovery, filtering, and deconvolution, and for the generation of the synthetic (Fig. 6) from the physical properties data, failed to produce strong midsection reflections.

\section{Site 884 Seismic Stratigraphic Correlation}

The well tie for Site 884 relies on correlation of the spacing and character of reflections on the processed seismic sections to a synthetic seismogram (Fig. 6), calculated from downhole log and rebound-corrected physical properties data, using a source pulse from an 80 -in. ${ }^{3}$ water gun. The seismic data collected with two water guns, had higher frequencies and a greater bandwidth compared to the synthetic trace (Fig. 4). Part of this difference is probably caused by the limits of resolution in averaging the physical properties over a few meters to calculate impedances.

Pronounced velocity offsets and inflections in downhole logs from Hole $884 \mathrm{E}$, and from physical properties measurements on cores from Holes $884 \mathrm{~B}, 884 \mathrm{C}$, and $884 \mathrm{E}$, were compared and picked to provide control points for calculation of a velocity-depth function. Depths corresponding to large density variations were noted and converted to two-way traveltime using the velocity-depth function described above. Other depths of geological interest were converted to two-way traveltime to show their placement with respect to seismic reflections or reflection sequences. These include lithologic breaks and horizons of interest that would not be expected to generate reflections (e.g., thin strata, chronologic boundaries, and magnetic boundaries).

The seismic section has about $1.047 \mathrm{~s}$ TWT of reflective section with seven distinctive sequences that can be correlated to the stratigraphy and physical properties. Over a wide range of filter settings, the top $166 \mathrm{~ms}$ has strong reflections, as does the basal $320 \mathrm{~ms}$, with only a few continuous reflections over the middle portion of the section comprising diatom ooze and diatomite. Increasing the gain within the middle portion of the section amplifies uncorrelated noise, and resolves a few continuous but weak reflections in addition to horizons with discontinuous reflections. A detailed correlation and causes for the various reflections follows. All physical properties data and lithostratigraphy referred to correspond to information given in (Rea, Basov, Janecek, Palmer-Julson, et al., 1993).

Lithologic Subunit IA is the uppermost zone with continuous high-frequency reflections. At the position of Site 884, shotpoint 1293 on the De-4a profile and shotpoint 1858 on the DE-4c profile (Fig. 7), there are six strong reflections above the Subunit IA/IB contact (128 mbsf, $166 \mathrm{~ms}$ bsf) (Figs. 6, 10). These reflections laterally increase to about 10 by the east-northeast end of Line De-4a (Fig. 10), implying there is an expanded section with better resolution for this upper part of the stratigraphy. The dropstone maximum at $25 \mathrm{mbsf}$ 


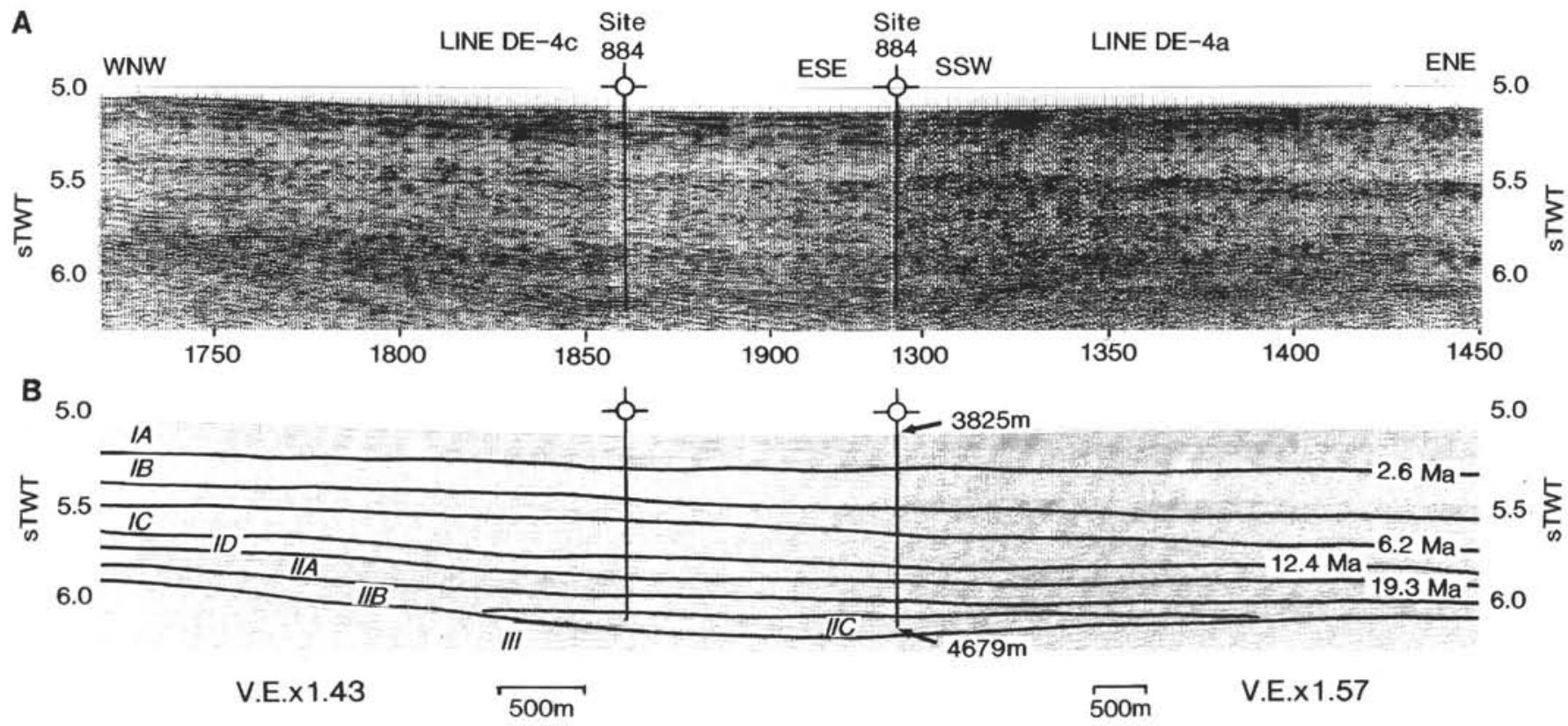

Figure 10. Portions of processed digital, single-channel seismic Profiles DE-4c and DE-4a joined where they meet at right angles over Site 884 in the Meiji Drift (A) and interpretation (B). Location information is given in Table 5 and Figure 7. The bold black line indicates the site location. Depth below sea level of the seafloor and maximum depth of penetration are shown. V.E. denotes vertical exaggeration, assuming a seawater velocity of $1500 \mathrm{~m} / \mathrm{s}$. Processing routines in sequence were MUTE, WBT, WEIGHT, DECON, FILTER, AVENOR, AGC, and MIX using the parameters listed in Table 1. Lithostratigraphic units and ages are from Rea, Basov, Janecek, Palmer-Julson, et al. (1993).

occurs between the seafloor and the first subsea reflection on the seismic section. Because of offsets in the physical properties data and the lack of logs for the uppermost 65 mbsf, it is not possible to tie the shallowest two reflections uniquely to the section. The third strong reflection at about $108 \mathrm{~ms}$ bsf corresponds to fluctuations in density and velocity at $82-83 \mathrm{mbsf}$. The fourth strong reflection at $124 \mathrm{~ms}$ bsf arises from density increases seen on the downhole log and the GRAPE, and fortuitously corresponds to the depth of the Olduvai magnetic event at 96 mbsf. A velocity decrease and inflection at 117 mbsf apparently generates the reflection at $151 \mathrm{~ms}$ bsf, just $7 \mathrm{~ms}$ above the projected position for the Matuyama/Gauss boundary. This reflection permits the magnetic and time horizon to be correlated laterally away from the site. The lowest reflection in this upper high-frequency reflective zone occurs at $166 \mathrm{~ms}$ bsf, and apparently arises from strong density fluctuations caused by changing proportions of clay and carbonate from 128 to $131 \mathrm{mbsf}$. The overall reflective character of this upper interval is caused by its layered and variable lithology, involving clay, carbonate, diatoms, dropstones, and ash.

Subunit IB, the clayey diatom ooze and clayey diatomite from 128 to $440.2 \mathrm{mbsf}$ ( $166-546 \mathrm{~ms}$ bsf) has few strong or continuous reflections, but more than ten reflections of weak to moderate amplitude and intermittent continuity, as shown on the synthetic seismogram for Site 884 (Fig. 6). The average mistie for reflections in this unit is $3 \mathrm{~ms}$ (about $2.4 \mathrm{~m}$ ). Over this part of the section there are five intervals that alternate between higher and lower frequencies. The three regions with higher frequency content (166-203, 275-327, and 386$546 \mathrm{~ms}$ bsf) owe this character to more intense small-scale fluctuations in velocity and density, relatively high clay contents, and more variable clay and carbonate components compared to the prevalent diatoms. The strongest of the low-frequency reflections, of weak to moderate amplitude and intermittent continuity, occur at 217, 253, 283,404 , and $496 \mathrm{~ms}$ bsf, arising from inflections or local extremes in velocity and density at about 173, 203, 224, 327, and 386 mbsf.

For using the seismic Lines De-4c and De-4a (Fig. 10) to follow geologic or chronologic horizons, other ties of interest in this interval are as follows. The lower/upper Pliocene and Gauss/Gilbert bound- ary coincides with a density decrease and a reflection at $234 \mathrm{~ms}$ bsf (180 mbsf). A reflection at $346 \mathrm{~ms}$ bsf and caused by a thin high-density layer from 272.5 to 275 mbsf marks the lower Pliocene/upper Miocene boundary. The Gilbert/C3A boundary occurs within an interval of discontinuous high-frequency reflections at about $393 \mathrm{~ms}$ bsf.

A continuous reflection at $404 \mathrm{~ms}$ bsf ( $318 \mathrm{mbsf}$ ) marks the base of a high-frequency zone that arises from density variations on a scale of 3-7 m. The section above this level is fairly constant in thickness but laterally somewhat variable in character. Downsection from this level, reflections show increasing drape and lap. The lowest ash in Subunit IB, with a slight density increase at $343 \mathrm{mbsf}$, occurs just below this last continuous reflection at $434 \mathrm{~ms}$ bsf. A discontinuous reflection, caused by a slight density increase at $363 \mathrm{mbsf}$, occurs at $456 \mathrm{~ms}$ bsf, about two-thirds of the way through a low-frequency or more transparent interval. This approximates the $\mathrm{C} 3 \mathrm{~A} / \mathrm{C} 3 \mathrm{~B}$ boundary.

Another high-frequency zone, beginning with a discontinuous reflection at $496 \mathrm{~ms}$ bsf, probably arises from carbonate-related density increases between 388 and $422 \mathrm{mbsf}$. The Subunit IB/IC and lower Pliocene/upper Miocene boundary occurs at $551 \mathrm{~ms}$ bsf ( $440.2 \mathrm{mbsf}$ ) within this high-frequency zone, and can be intermittently tracked by a reflection near $546 \mathrm{~ms}$ bsf. The basal part of this high-frequency section shows wedging and downlap, with a thickening of the overlying section toward the east. Seismically, the base of Subunit IB looks like an unconformity, implying continuous sedimentation rates should not be calculated across this interval.

The high-frequency discontinuous reflections present in the base of Subunit IB (Fig. 10) persist to $572 \mathrm{~ms}$ bsf (about $458 \mathrm{mbsf}$ ) within the top of the Subunit IC claystone. A reflection at $572 \mathrm{~ms}$ bsf (Fig. 6) marks the top of a series of density and lithology changes associated with the sandstone and turbidite sequence near $460 \mathrm{mbsf}$. From here to the base of this subunit, reflections are related to density and clay content variations.

The next throughgoing reflection occurs at $631 \mathrm{~ms}$ bsf. This reflection is associated with density increases from 505 to $522 \mathrm{mbsf}$ 
and coincidentally marks the upper/middle Miocene boundary and the shallowest occurrence of metallic copper in Hole 884B. Immediately below this, a somewhat stronger and more coherent reflection occurs at $656 \mathrm{~ms}$ bsf, fortuitously marking the base of the zone with metallic copper occurrences at 526.7 mbsf. A weak reflection at 678 $\mathrm{ms}$ bsf marks the base of Subunit IC at $546.1 \mathrm{mbsf}$ and the base of another zone of discontinuous high-frequency reflections.

Subunit ID diatomite (546.1-604.8 mbsf) occurs from 678 to 747 $\mathrm{ms}$ bsf on the seismic section (Fig. 10). The reflections in this relatively transparent zone have low amplitudes and poor continuity. The reflection at $711 \mathrm{~ms}$ bsf is related to a density increase at $576 \mathrm{mbsf}$.

The section for all of Unit II claystone has dipping, upward-curving convex reflections of moderate to strong amplitude with lateral continuity less than 20-30 shots (roughly $600-900 \mathrm{~m}$ ). This provides a measure of how far the facies and physical properties measured for this unit in the drill hole apply. The basal part of the sedimentary succession thickens and dips downslope to the southeast on Line De-4c and is thickest in the vicinity of the site on Line De-4a (Fig. 10). This seismic facies is local to Site 884 and has the appearance of slumps. The reflection at $747 \mathrm{~ms}$ bsf marks the Subunit ID/IIA transition from diatomite back into claystone, although the cause of this reflection is probably a high-density bed at $605.5-607 \mathrm{mbsf}$, rather than the lithostratigraphic boundary described (Rea, Basov, Janecek, PalmerJulson, et al., 1993). A strong continuous reflection at $755 \mathrm{~ms}$ bsf correlates to the turbidite at $608.6 \mathrm{mbsf}$ and to density variations from here to $617 \mathrm{mbsf}$. A more continuous but slightly weaker reflection at $772 \mathrm{mbsf}$ ties to the large decrease in density downsection associated with the transition from clay to carbonate. The reflection of moderate amplitude and continuity at $816 \mathrm{~ms}$ bsf originates from the claystone/chalk boundary at $662 \mathrm{mbsf}$ within the Oligocene portion of Subunit IIA. A reflection at $832 \mathrm{~ms}$ bsf originates from intense density fluctuations near 673 and 678 mbsf.

The reflection at $850 \mathrm{~ms}$ bsf ties to the Subunit IIA/IIB boundary between early Miocene claystone and late Eocene chalk. Velocity abruptly increases downsection here, and the GRAPE density shows intense variations throughout this interval. Subunit IIB is characterized by a few low-frequency reflections, with one at $911 \mathrm{~ms}$ bsf correlating to a diamictic conglomerate at $750 \mathrm{mbsf}$.

A reflection at $939 \mathrm{~ms}$ bsf $(771 \mathrm{mbsf}$ ) (Figs. 6, 10) marks the Subunit IIB/IIC boundary to the underlying early-middle Eocene and older claystone and altered ash. The lack of downhole logs make assignment of specific causes in density or velocity uncertain from here to basement. The basal sedimentary reflections are flat-lying, with moderate amplitudes and periods of $15-20 \mathrm{~ms}$. This basal section onlaps basement and the section thickens, picking up progressively older strata away from the drill site toward the southeast. A reflection $<200 \mathrm{~m}$ across at $962 \mathrm{~ms}$ bsf marks the depth of the conglomerate noted at $796.4 \mathrm{mbsf}$. A reflection at $972 \mathrm{~ms}$ bsf ties to the base of the turbidites at $799.2 \mathrm{mbsf}$. The copper noted at $806.1 \mathrm{mbsf}$ projects to $978 \mathrm{~ms}$ bsf.

The tie to basement is uncertain to within $\pm 75 \mathrm{~ms}( \pm 260 \mathrm{~m})$. The lack of downhole logs, the scatter in velocities from core specimens, the offset of the site from the seismic lines, and the complex reflections in this region are all confounding factors. There is a strong reflection at $995 \mathrm{~ms}$ bsf that is overlain by onlapping reflections assigned to the turbidites and reworked facies higher upsection. This looks like the sediment/basement unconformity on seismic Lines De$4 \mathrm{a}$ and De-4c (Fig. 10). Strong intermittent reflections with about a 25 -ms period persist from here to about $1063 \mathrm{~ms}$ bsf.

The seismic character of the lowest part of the sedimentary succession resembles near-basement volcano-sedimentary packages like those drilled and extensively modelled at Middle Valley on the Juan de Fuca Ridge (Rohr and Schmidt, 1994). The reflection at $1019 \mathrm{~ms}$ bsf can be converted to an equivalent depth of $848.2 \mathrm{mbsf}$, at which depth basalt was found in Holes $884 \mathrm{~B}$ and $884 \mathrm{E}$. The problem is that this reflection is not particularly strong or continuous with respect to neighboring ones and there are reflections as much as $200 \mathrm{~ms}(600$ $\mathrm{m}$ ?) deeper. The Subunit IIC/Unit III boundary, between reworked claystone-ash-chalk and basalt, could occur at 995, 1019, 1047, or $1063 \mathrm{~ms}$ bsf. The favored interpretation from the seismic record is that the base of this site penetrated a basalt sill or flow in a near-basement, interbedded, basalt-sediment facies but did not quite penetrate the Cretaceous ocean crust.

\section{Site 884 Interpretation}

The most significant finding for this site is that small-scale variations of reflection character (Fig. 10) and physical properties within the clayey diatom ooze of Subunit IB suggest five distinctive cycles of deposition. This cyclicity manifests itself in the alternating finer and coarser reflections and in corresponding fine to coarse fluctuations in density. This cyclic variation is analogous to, but less intense than that documented for the acoustic stratigraphy of deep-sea carbonate (Mayer, 1991; Mosher et al., 1993; Bloomer et al., 1995) and mixed carbonate-siliciclastic ooze records (Mayer et al., 1985) from elsewhere in the Pacific.

The discontinuous high-frequency reflection stripes within the portion of the seismic record attributed to the diatom ooze are a regional feature for all three of the seamount and abyssal seafloor sites at Wayne, Detroit, and Meiji, irrespective of lithologic contrasts between Subunit IB at Site 882 (Fig. 5) and Site 884 (Fig. 10), and Unit II at Site 883 (Fig. 8). This interval holds promise for investigations of cyclicity in the seismic stratigraphy, downhole logs, and physical properties data relating to the oceanographic, tectonic, and climatic controls seen at such sites as Site 574 (Mayer et al., 1985). It also justifies the acquisition of high-resolution digital seismic records in abyssal hemipelagic settings.

\section{Sites 885 and 886 Seismic Survey Parameters}

The survey for Sites 885 and 886 is located in the middle of the northern Pacific, just to the south of the Chinook Trough and southwest of the Zodiac Fan (Fig. 11). The site was chosen on the basis of regional information and this survey. There were no site selection survey data for the comparison of records. The survey for Sites 885 and 886 collected $45.9 \mathrm{~km}$ of single-channel seismic data, as three profiles arranged like a backward numeral 4 rotated on its side, with Line AP-5c oriented nearly east-west (Table 6; Fig. 11). The seismic source consisted of a single 80 -in. ${ }^{3}$ water gun. The shot spacing ranged from 24 to $28 \mathrm{~m}$. The single-channel lines were digitized at 1 $\mathrm{ms}$ and processed as described in Table 1 . With $392 \mathrm{~m}$ of tow leader, the offset for the seismic trace is $304 \mathrm{~m}$ behind the GPS fix, and 325 $\mathrm{m}$ behind the high-resolution profiles. The time switch for simulating the blast phone was inadvertently left on through most of Line AP-5a (Fig. 12). This introduced a static delay of $90 \mathrm{~ms}$, which was dealt with surgically as a time shift using the routine water bottom time (WBT). As a consequence the two-way traveltimes on the processed version of Line AP-5a do not coincide with the appropriate water depth nor with the remainder of the survey for this site. Compared to the mud line, Line AP-5a (Fig. 12) comes in $21 \mathrm{~ms}$ slow (16 m too deep).

Because of the thin sedimentary section at this abyssal plain site, the seismic record length was $2 \mathrm{~s}$ of which only $0.6 \mathrm{~s}$ TWT was processed. Site 885 , in a local lens of sediment, has a good tie, being located only $63 \mathrm{~m}$ off Line AP-5a (Fig. 11). Coring problems caused the position of the subsequent hole (Site 886) to be shifted $5.4 \mathrm{~km}$ away, following the seafloor character on a $3.5-\mathrm{kHz}$ sounding profile. The tie for Site 886 relies on correlations between the two holes, rather than on a tie to the seismic data. There is about a $6.2 \mathrm{~m}$ vertical offset between the two holes in the physical properties data, with Site 886 having that much more young strata on top. The sections have good resolution, despite the problems in processing such short records with the SIOSEIS system. The biggest limitation in processing these sections is that the sediment section is thin compared to the 
A

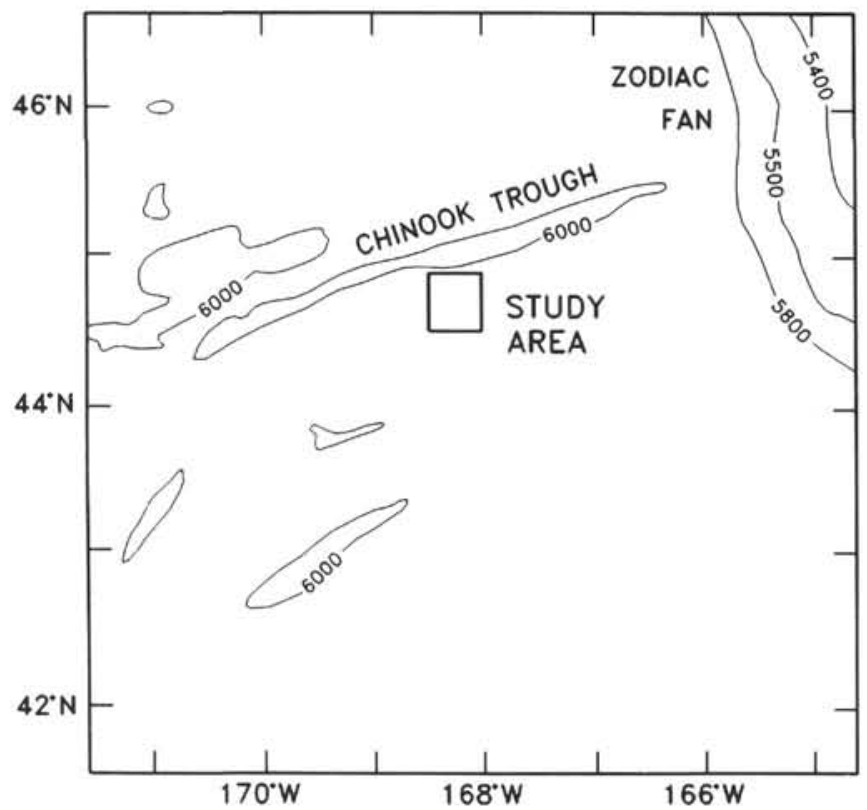

B

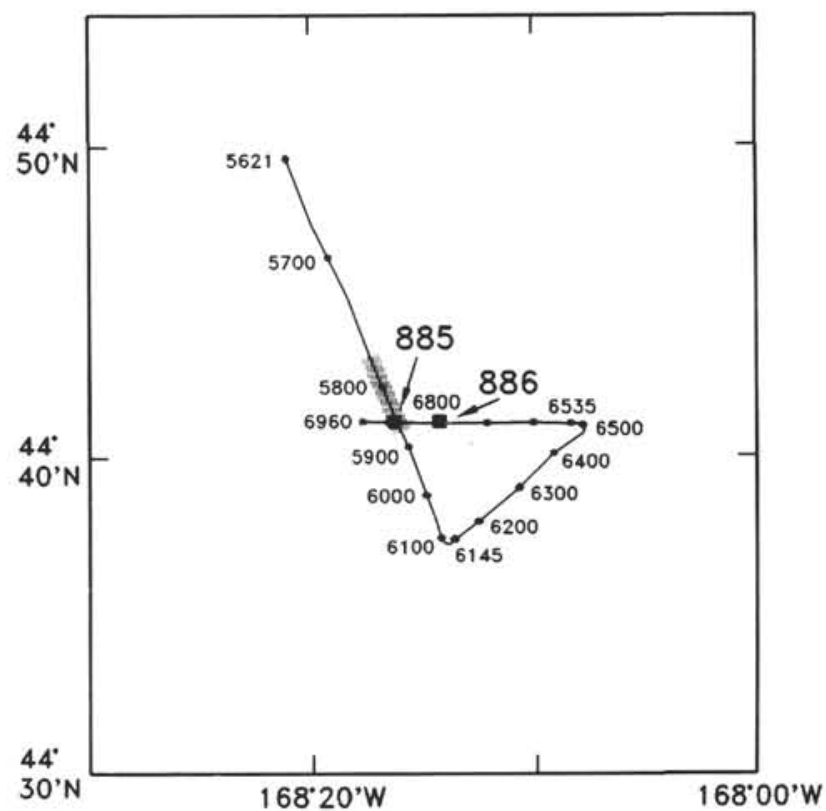

Figure 11. Regional bathymetric setting (A) and location of site occupancy survey for Sites 885 and 886 (B) on the southeast edge of the Chinook Trough. Bathymetry after GEBCO Chart 5.07 (Udintsev, 1982). Shotpoint numbers are annotated with time ties provided in Table 6. Shading corresponds to the profile shown in Figure 12.

Table 6. Location parameters for seismic survey of Sites 885/886.

\begin{tabular}{clccccc}
\hline Site & Line & Day & Time & Shot & Latitude (N) & Longitude (W) \\
\hline \multirow{2}{*}{885} & AP-5a & \multirow{2}{*}{247} & 1300 & 5621 & $44^{\circ} 49.661^{\prime}$ & $168^{\circ} 21.266^{\prime}$ \\
& EOL & & 1530 & 6145 & $44^{\circ} 37.416^{\prime}$ & $168^{\circ} 13.649^{\prime}$ \\
885 & TIE & & 1436 & 5822 & 2 shots & $633 \mathrm{~mW}$ \\
& AP-5b & & 1530 & 6145 & $44^{\circ} 37.416^{\prime}$ & $168^{\circ} 13.649^{\prime}$ \\
& EOL & & 1637 & 6535 & $44^{\circ} 41.124^{\prime}$ & $168^{\circ} 08.779^{\prime}$ \\
& AP-5c & & 1637 & 6535 & $44^{\circ} 41.124^{\prime}$ & $168^{\circ} 08.779^{\prime}$ \\
& EOL & \multirow{2}{*}{1748} & 6960 & $44^{\circ} 41.316^{\prime}$ & $168^{\circ} 17.592^{\prime}$ \\
886 & TIE & 247 & & $6830-6997$ & Off EOL & $5437 \mathrm{~m} \mathrm{NE}$ \\
\hline
\end{tabular}

\begin{tabular}{|c|c|c|c|c|c|c|}
\hline Line & $\begin{array}{l}\text { Length } \\
\text { (m) }\end{array}$ & Shot & $\begin{array}{l}\text { Time } \\
(\mathrm{min})\end{array}$ & $\begin{array}{c}\text { Seconds/ } \\
\text { shot }\end{array}$ & $\begin{array}{c}\text { Meters/ } \\
\text { shot }\end{array}$ & $\begin{array}{c}\text { Kilometers/ } \\
\mathrm{hr}\end{array}$ \\
\hline$-5 a$ & 24,813 & 881 & 150 & 10.2 & 28.2 & 9.93 \\
\hline$-5 b$ & 9.415 & 390 & 54 & 8.31 & 24.1 & 10.5 \\
\hline$-5 c$ & 11,652 & 425 & 71 & 10.0 & 27.4 & 9.85 \\
\hline
\end{tabular}

filter and operator lengths needed by SIOSEIS. An additional complication is that near these sites, the basement relief is double the maximum sediment thickness. Near Site 885, Line AP-5c (not shown) has $40 \mathrm{~ms}$ of basement relief over $164 \mathrm{~m}$ (slope $>10^{\circ}$ ). This is significant for the well tie to basement. All three seismic profiles for these two sites show strong out-of-line diffractions from nearby basement highs.

\section{Site 885 Seismic Stratigraphic Correlation}

Despite the thin sediment at this site, the tie to the seismic section (Fig. 12) is good. Ties were made by predicting reflection times from lithologic breaks and fluctuations in the density and impedance profiles. Interval velocities from physical properties data were averaged and scaled by 1.006 to account for core expansion. This resulted in an average velocity to the base of core of $1514.3 \mathrm{~m} / \mathrm{s}$. The predicted reflection times were correlated to reflections on the seismic section at shotpoint 5822 , with an average mistie of $2 \mathrm{~ms}$ ( $3 \mathrm{~m}$ ). Finally, a synthetic seismogram generated from the physical properties data using an 80 -in. ${ }^{3}$ water gun source pulse was tied to the section. The synthet- ic seismogram for Site 885 (Fig. 6) matched the reflection's phases and amplitudes, but it did not have the high-frequency character or resolution of the seismic section.

Because of the nearly constant velocity through the sediment section, reflections correspond to density, impedance, and lithology changes. The late Pliocene to Pleistocene brown clay of Unit I ( 0 $17.3 \mathrm{mbsf}$ ) occurs from 0 to $24 \mathrm{~ms}$ bsf, having two or three low-amplitude reflections with approximately an $8-\mathrm{ms}$ period and a lateral continuity of $<200 \mathrm{~m}$. The reflection at $18 \mathrm{~ms}$ bsf is the most continuous and corresponds to a density and impedance minimum at about 13 mbsf.

The late Miocene to late Pliocene brown diatom ooze of Unit II (17.3-50.3 mbsf) occurs between 24 and $67 \mathrm{~ms}$ bsf (Fig. 12). Its basal contact gives a strong continuous reflection that occurs about twothirds of the way through the sediment column, irrespective of the variation in sediment thickness. Within Unit II, there is a reflection at $34 \mathrm{~ms}$ bsf that is lower in amplitude and less continuous. It corresponds to a density and impedance minimum in Hole $885 \mathrm{~A}$ at $24 \mathrm{~m}$ and in Hole $886 \mathrm{~B}$ at $30.5 \mathrm{~m}$.

The late Miocene dark brown clay of Unit III (50.3-71.9 mbsf) occurs from 67 to $76 \mathrm{~ms}$ bsf (Fig. 12). Internally nonreflective, this unit laterally increases in thickness by a factor of four compared to the drill sites, because of relief on its basal contact.

The reflection at $76 \mathrm{~ms}$ bsf (Fig. 12) is the strongest in the section and is basalt from the tie to the core. It is the base of the holes, but it is not the base of the reflective section. The continuous acoustic basement reflection occurs at $105 \mathrm{~ms}$ bsf ( $22 \mathrm{~m}$ below TD) at Site 885 , and is recognized by the envelope of diffractions and lack of deeper reflections. At most places, this reflection is nearly equal in amplitude to the reflection at $76 \mathrm{~ms}$ bsf. Furthermore, it is more continuous and has less relief. It is tentatively suggested that Sites $885 / 886$ bottomed in a mixed flow and palagonite tuff (or sediment) unit that variably overlies a section of continuous flows.

\section{Sites 885 and 886 Interpretation}

Across the surveyed area, partially shown in Figure 12, the thickness of the sediment section varies from 0 to $140 \mathrm{~ms}$. All reflections exhibit dip and drape and have an onlapping relation to the basalt. 


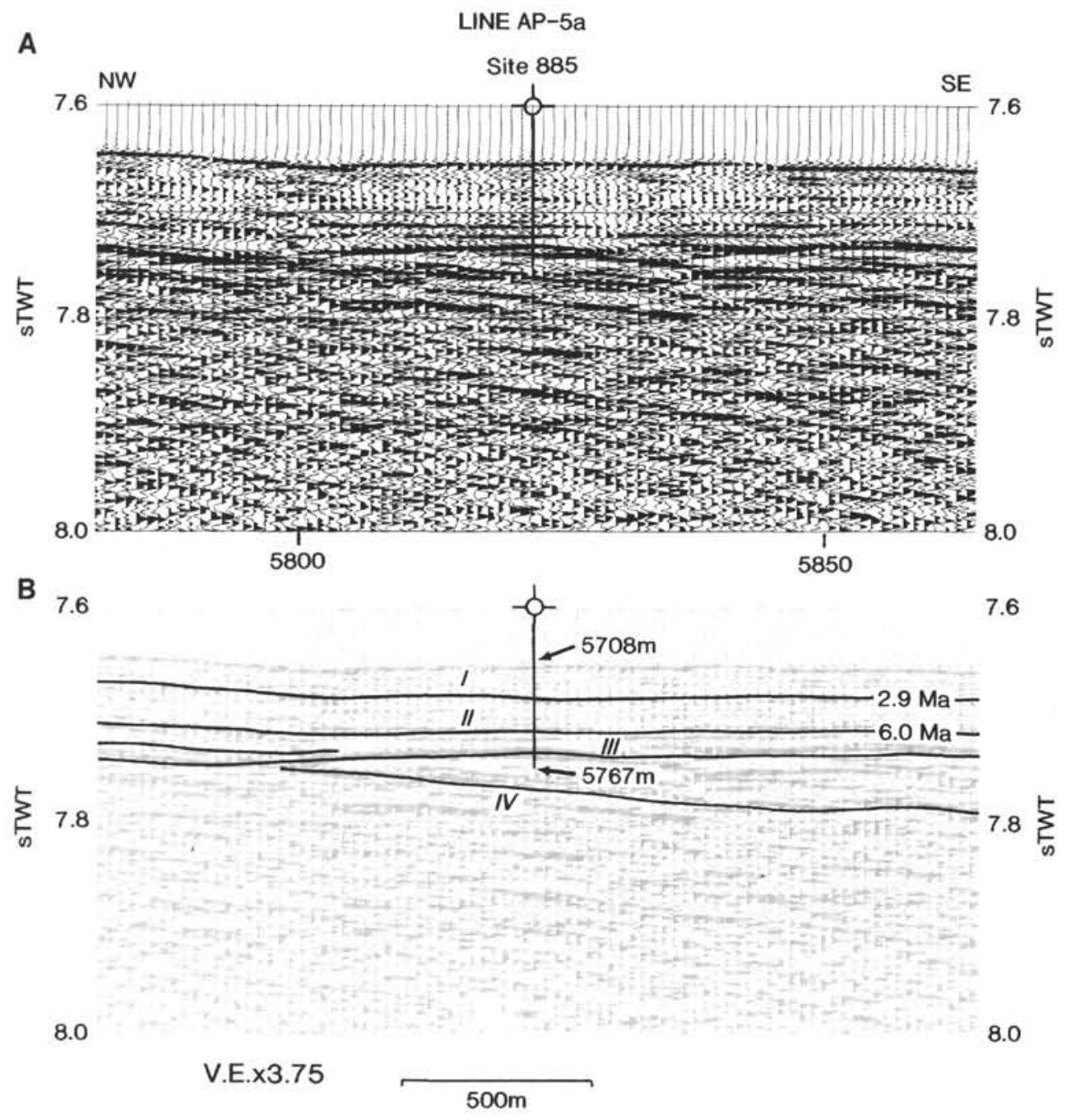

Figure 12. Processed, digital, single-channel seismic Profile AP-5a through Site 885 in the Abyssal Seafloor/Chinook Trough (A) and interpretation (B). Location information is given in Table 6 and Figure 11. The bold black line indicates the site location. Depth below sea level of the seafloor and maximum depth of penetration are shown. V.E. denotes vertical exaggeration, assuming a seawater velocity of $1500 \mathrm{~m} / \mathrm{s}$. Processing routines in sequence were SHIFT, WBT, MUTE, DECON, FILTER, AGC, and MIX using the parameters listed in Table 1. Lithostratigraphic units and ages are from Rea, Basov, Janecek, Palmer-Julson, et al. (1993). The label for Unit IV has been placed at acoustic basement rather than at total depth.

Units I and II are the most widespread. It appears that Unit III varies from 0 to $70 \mathrm{~ms}$ thick (and is thickest at shotpoint 5440 on Line AP5a; Fig. 12). This location would be a suitable target for a longer, older brown clay record. Unit IV usually fills troughs and is not seen on the more rugged and shallower areas. The thin sediment section here and the high-resolution records provide an instructive example for the near-basement facies elsewhere during Leg 145.

Unit IV (Fig. 12) is probably close to the age of the underlying basaltic crust because it shows fault offsets that are not seen higher in the section. This suggests early faulting of this region of ocean crust, perhaps associated with movement away from its ridge. The interpretation of these near-basement faults also bears on arguments for the existence and timing of tectonic reactivation and geochemical changes discussed for these sites (Rea, Basov, Janecek, Palmer-Julson, et al., 1993).

\section{Site 887 Seismic Survey Parameters}

This site survey covers an elevated platform on the flank of the Murray Seamount in the northeast Pacific (Figs. 1, 13). The survey consisted of $39.0 \mathrm{~km}$ of profiles in the shape of the numeral 4 rotated $82^{\circ}$ clockwise so that Line PM-1a is nearly east-west (Table 7; Fig. 13). The seismic data consisted of 4-s-long single-channel seismic records digitized at $1 \mathrm{~ms}$. Processing data are given in Table 1 . Only the 80 -in. ${ }^{3}$ water gun was functional for this survey. Speed over the ground varied by about $40 \%$ between the lines, resulting in highly variable vertical exaggeration for the three sections.

Line PM-1a successfully replicates the portion of the Parizeau profile (19 August 1987; 1550-1700 hr; from Bornhold et al., 1989) used to select the site. Figure 14 comprises portions of two seismic records: Line PM-1c, approaching the site from the south, and Line PM-1a, leaving the site toward the east (Table 7; Fig. 13). The two lines cross the site at nearly right angles to each other. The offset in timing lines occurs because Line PM-1a was recorded with the blast phone simulation switch on. Correct two-way traveltimes correspond to those for Line PM-1c on the left-hand side of the figure. The processed digital records show the upper $150 \mathrm{~ms}$ and the near-basement section to be the most reflective. Approximately $440 \mathrm{~ms}$ of reflective section overlies the envelope of diffractions that denotes the top of the basaltic basement. 


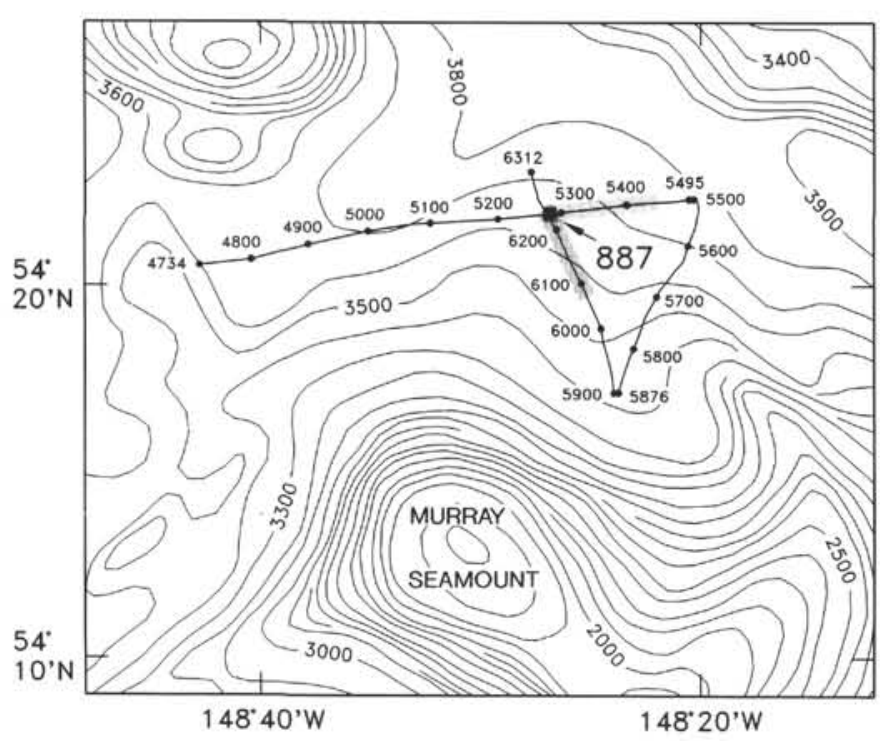

Figure 13. Regional bathymetric setting and location of site occupancy survey for Site 887 on the north flank of Murray Seamount. Bathymetry from Bornhold et al. (1989). Shotpoint numbers are annotated with time ties provided in Table 7. Shading corresponds to the portions of seismic profiles shown in Figure 14.

\section{Site 887 Seismic Stratigraphic Correlation}

The well tie for Site 887 has the correct seafloor arrival time to within $1 \mathrm{~ms}$. This and the successful reflection assignments confirm that the site is correctly located with respect to the seismic lines. The well tie depends on a velocity function derived from the shipboard physical properties data. Inflections in the trends of the density and velocity profiles vs. depth, and values showing the largest offsets, were selected as possible reflections. Because of the small number of velocity measurements, median velocities for those depth intervals were used to calculate two-way traveltimes for a list of hypothetical reflections. This list was compared to the most prominent and continuous reflections on the seismic section to provide the following correlation.

The seafloor and top of the Pleistocene gray clay of Subunit IA (Fig. 14) occurs at $4.861 \mathrm{~s}$ TWT. Unit I has 11 or more high-frequency reflections, with the strongest occurring at $4.880 \mathrm{~s}$ TWT about halfway through the unit. The reflections in the basal half of this unit are more continuous than those in its upper part, implying the uppermost section of Unit I to be laterally variable. The basal reflection in this uppermost high-frequency zone occurs at $4.916 \mathrm{~s}$ TWT, which is only $3 \mathrm{~ms}$ shallower than the predicted contact between Subunits IA and IB, and coincidentally, the Brunhes/Matuyama boundary.

The contact between Subunits IB and IIA (90 mbsf) is a weak reflection occurring at $4.978 \mathrm{~s}$ TWT (Fig. 14). Two stronger and more continuous reflections at 4.945 and $4.963 \mathrm{~s}$ TWT make distinctive markers within the clay-diatom ooze of Subunit IB, approximating the base of the Pleistocene and the Matuyama/Gauss boundary, respectively, allowing them to be mapped seismically.

The relatively nonreflective middle portion of the seismic sections is the Unit II diatom ooze (90-270 mbsf, 4.978-5.215 s TWT). Subunit IIA (90-174 mbsf, 4.978-5.086 s TWT) is slightly reflective in its upper $30 \%$ but the reflection continuity does not exceed $200 \mathrm{~m}$ laterally. The lower $70 \%$ of this interval, below $5.010 \mathrm{~s}$ TWT, is transparent.

The time ties for the Gauss/Gilbert and upper/lower Pliocene boundary (5.003 s TWT), the deep 4.6-Ma dropstones $(5.029 \mathrm{~s}$
Table 7. Location parameters for seismic survey of Site 887.

\begin{tabular}{clccccc}
\hline Site & Line & Day & Time & Shot & Latitude (N) & Longitude (W) \\
\hline \multirow{2}{*}{887} & PM-1a & 253 & 1850 & 4734 & $54^{\circ} 20.967^{\prime}$ & $148^{\circ} 41.149^{\prime}$ \\
& EOL & & 2110 & 5495 & $54^{\circ} 21.820^{\prime}$ & $148^{\circ} 21.588^{\prime}$ \\
887 & TIE & & 2034 & 5278 & \pm 29 shots & $449 \mathrm{~m} \mathrm{NW}$ \\
& PM-Ib & & 2110 & 5495 & $54^{\circ} 21.820^{\prime}$ & $148^{\circ} 21.588^{\prime}$ \\
& EOL & & 2220 & 5876 & $54^{\circ} 17.966^{\prime}$ & $148^{\circ} 23.473^{\prime}$ \\
& PM-Ic & 2220 & 5876 & $54^{\circ} 17.966^{\prime}$ & $148^{\circ} 23.473^{\prime}$ \\
& EOL & 2340 & 6312 & $54^{\circ} 22.941^{\prime}$ & $148^{\circ} 27.708^{\prime}$ \\
887 & TIE & & 2325 & 6231 & \pm 8 shots & $230 \mathrm{~m} \mathrm{NW}$ \\
\hline
\end{tabular}

\begin{tabular}{rrrrrrr}
\hline Line & $\begin{array}{c}\text { Length } \\
(\mathrm{m})\end{array}$ & Shot & $\begin{array}{c}\text { Time } \\
(\mathrm{min})\end{array}$ & $\begin{array}{c}\text { Seconds/ } \\
\text { shot }\end{array}$ & $\begin{array}{c}\text { Meters/ } \\
\text { shot }\end{array}$ & $\begin{array}{c}\text { Kilometers/ } \\
\text { hr }\end{array}$ \\
\hline -1a & 21,249 & 761 & 140 & 11.0 & 27.9 & 9.11 \\
- Ib & 7,434 & 381 & 70 & 11.0 & 19.5 & 6.37 \\
- Ic & 10,305 & 436 & 80 & 11.0 & 23.6 & 7.73 \\
\hline
\end{tabular}

in this nonreflective interval. The calcareous diatom ooze of Subunit IIB (174-235 mbsf, 5.086-5.165 s TWT) has one continuous reflection at $5.148 \mathrm{~s}$ TWT, which, although a little shallow, is the sole opportunity the seismic section affords to track the base or to approximate the thickness of this subunit. The top of the lower ash succession, the base of the $N$. kamtschatica zone, and the $\mathrm{C} 3 \mathrm{~B} / \mathrm{C} 4$ magnetostratigraphic boundary occur midway through this unit at $5.119 \mathrm{~s}$ TWT, just above the solitary $5.148 \mathrm{~s}$ TWT reflection noted above. The clayey siliceous ooze of Subunit IIC (235-273.8 mbsf, $5.165-5.215 \mathrm{~s}$ TWT) has a weak reflection at its top and two slightly stronger reflections at 5.180 and $5.200 \mathrm{~s}$ TWT, corresponding to a density and velocity decrease at about $250 \mathrm{mbsf}$. These reflections are of limited use for correlation in that they extend only about 500 $m$ to either side of the site.

The thin, near-basement, brown clay and oxide Unit III (270-289 mbsf) is only 6 ms thick on the seismic section. Its predicted base at $5.221 \mathrm{~s}$ TWT is $3 \mathrm{~ms}$ above a prominent, continuous, $100-\mathrm{Hz}$ reflection (Fig. 14). From the lateral relief on this prominent reflection, it is likely that the brown clay varies from 0 to $15 \mathrm{~ms}(0-32 \mathrm{~m})$ thick.

The base of Unit IV as drilled ( $373 \mathrm{mbsf}$ ) is predicted to be at $5.259 \mathrm{~s}$ TWT, or about $5 \mathrm{~ms}$ too deep for the base of the first strong, near-basement reflection. This is acceptable, considering the variation in velocity measurements from this part of the section. The seismic section (Fig. 14) shows deeper reflections at 5.270 and $5.300 \mathrm{~s}$ TWT. It is likely, given the lateral character changes in this lower, strong-reflector facies, and given the measured velocities, that this part of the section is a near-basement sediment/sill complex about $175 \mathrm{~m}$ thick.

\section{Site $\mathbf{8 8 7}$ Interpretation}

The Unit I clays are the most consistent and widespread stratum. They are regional, and they drape relief on underlying units (Fig. 14). Seismically, this Pleistocene gray clay facies is distinctive and represents a different style of sedimentation (e.g., in terms of rates, density, and lateral heterogeneity) from the underlying Tertiary biogenic ooze. The sedimentary section thickens in the vicinity of Site 887 , as shown by the isopach map of Bornhold et al. (1989), and thins farther down the seamount flanks. This thickness variation depends almost entirely on the midsection diatom oozes. Downslope thinning is a persistent feature of these oozes, and many pairs of reflections can be seen to thin out in a downslope direction. The bounding reflections of the Unit II diatom ooze downlap to their basal contact off the sides of the platform. The seismic form of these ooze facies suggest that, from the middle Miocene to the upper Pliocene over Murray Seamount, there was a higher rate of biogenic sedimentation on top of the seamount compared to its flanks and adjacent deeps. This unusual seismic facies could be evidence for local upwelling and enhanced productivity over this and similar high-latitude seamount platforms. 
A

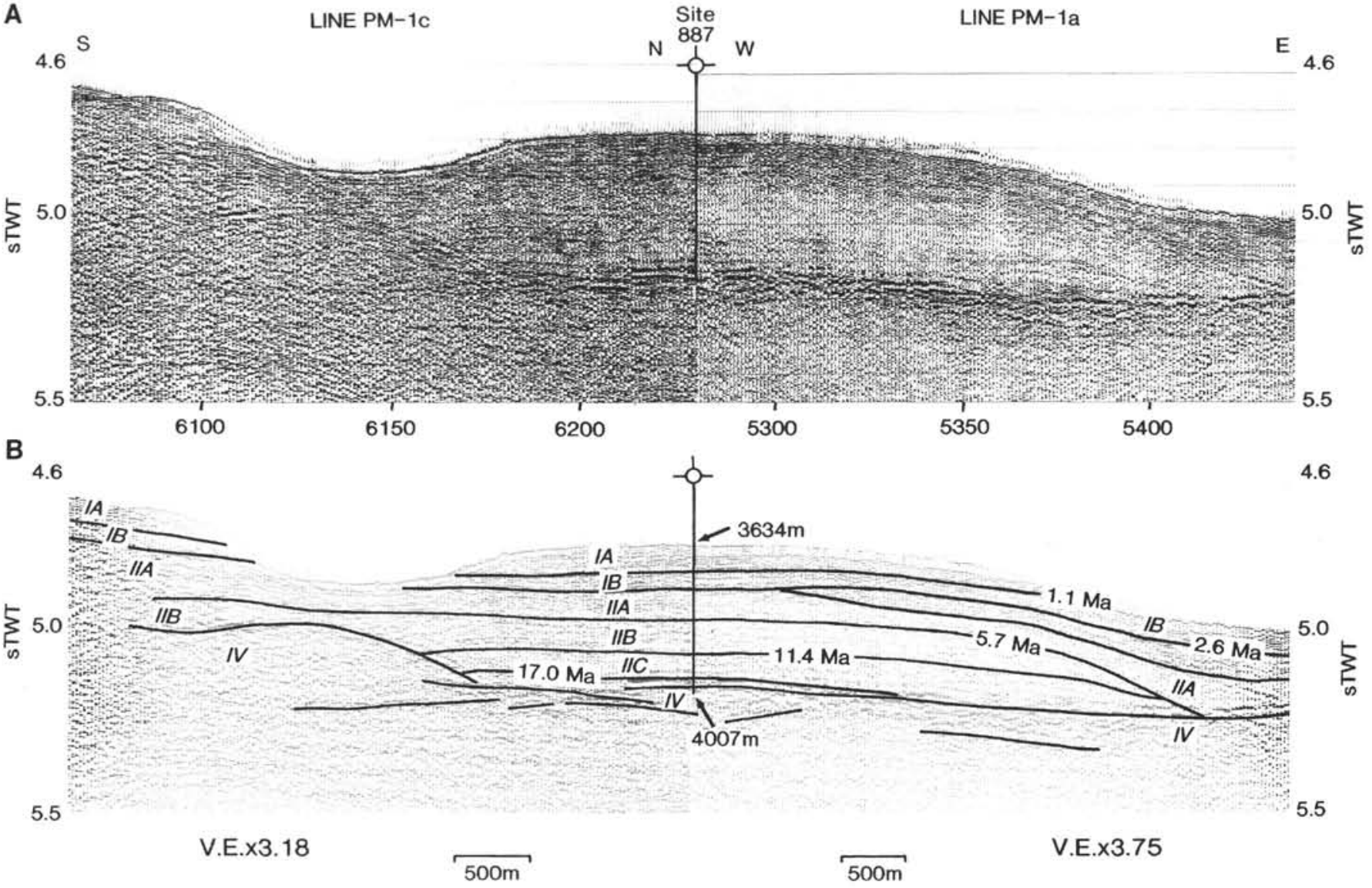

Figure 14. Portions of processed, digital, single-channel seismic Profiles PM-6a and PM-6c joined where they meet over Site 887 on the flank of Murray Seamount (A) and interpretation (B). Location information is given in Table 7 and Figure 13. The bold black line indicates the site location. Depth below sea level of the seafloor and maximum depth of penetration are shown. V.E. denotes vertical exaggeration, assuming a seawater velocity of $1500 \mathrm{~m} / \mathrm{s}$. Processing routines in sequence were MUTE, DECON, FILTER, AGC, and MIX using the parameters listed in Table 1. Lithostratigraphic units and ages are from Rea, Basov, Janecek, Palmer-Julson, et al. (1993). Unit III is too thin to be labeled on the figure.

\section{DISCUSSION}

Across the North Pacific the seismic stratigraphy as calibrated at Sites 881 through 887 has a distinctive three-part character. The uppermost seismic facies contains a series of high-frequency reflections that correspond to density and lithology variations in Pliocene-Pleistocene, distal and bathyal, glaciomarine sediments. Tectonic reactivation off the Zenkevich Rise locally amplifies this part of the section.

The middle seismic facies of diatom ooze, best seen at the Detroit $(882,883,884)$ and Murray $(887)$ seamount sites, exhibits drape of underlying units and is only faintly reflective or nonreflective. Gain recovery and spiking deconvolution on the processed sections reveal intermittent packages of fine-scale weak reflectors that correlate to slight fluctuations in the density of the diatom ooze. These types of cyclic reflectors are an order of magnitude weaker than those seen in the carbonate oozes of the mid-equatorial Pacific (Mayer, 1991; Bloomer et al., 1995) but at this latitude have little to offer in terms of correlatable cyclic stratigraphy. This middle Tertiary part of the section and underlying units show signs of tectonic deformations that long postdate crustal formation as well as provide evidence of intraplate deformation.

The basal seismic facies are strongly reflective, comparable to the top of the section but at lower frequencies. These units are unconformable, contain slumps, and show a sense of lap that is highly variable with only local continuity. These facies are best represented on this transect at the deflated abyssal Sites $885 / 886$ near the Chinook Trough.

\section{ACKNOWLEDGMENTS}

The author gratefully acknowledges Larry Mayer for making his synthetic program NEWSEIS available and Peter deMenocal and Jim Bristow for their help in reducing the physical properties data and helping to match the synthetics to the seismic sections during the leg. Helpful and constructive reviews were provided by Terry Bruns, Robert Embley, and David Scholl. Ralph Currie helped reduce and plot the navigation for the location figures. Milly Giarratano supplied the bathymetry for the Detroit Seamount region. Richard Franklin drafted the figures. This work was wholly supported by the Geological Survey of Canada, contribution no. 10294.

\section{REFERENCES*}

Bloomer, S.F., Mayer, L.A., and Moore, T.C., Jr., 1995. Seismic stratigraphy of the eastern equatorial Pacific Ocean: paleoceanographic implications. In Pisias, N.G., Mayer, L.A., Janecek, T.R., Palmer-Julson, A., and van Andel, T.H. (Eds.), Proc. ODP, Sci. Results, 138: College Station, TX (Ocean Drilling Program), 537-553.

*Abbreviations for names of organizations and publications in ODP reference lists follow the style given in Chemical Abstracts Service Source Index (published by American Chemical Society). 
Bornhold, B.D., Currie, R.G., and Sawyer, B., 1989. Patton-Murray Seamount Group: 3 maps: bathymetry, magnetic anomaly, sediment thickness, 1:250,000. Geol. Surv. Can. Open File, 2075,

Jacobi, R.D., and Hayes, D.E., 1989. Sedimentary effects of interplay between the Kuroshio extension and Pacific Plate motions. Geol. Soc. Am. Bull., 101:549-560.

Lonsdale, P., Dieu, J., and Natland, J., 1993. Posterosional volcanism in the Cretaceous part of the Hawaiian hotspot trail. J. Geophys. Res., 98:40814098.

Ludwig, W.J., and Houtz, R.E., 1979. Isopach map of sediments in the Pacific Ocean Basin and marginal sea basins. AAPG Map Ser., 647.

Mayer, L.A., 1991. Extraction of high-resolution carbonate data for paleoclimate reconstruction. Nature, 352:148-150.

Mayer, L.A., Shipley, T.H., Theyer, F., Wilkens, R.H., and Winterer, E.L., 1985. Seismic modeling and paleoceanography at Deep Sea Drilling Project Site 574. In Mayer, L.A., Theyer, F., Thomas, E., et al., Init. Repts. DSDP, 85: Washington (U.S. Govt. Printing Office), 947-970.

Mosher, D.C., Mayer, L.A., Shipley, T.H., Winterer, E.L., Hagen, R.A., Marsters, J.C., Bassinot, F., Wilkens, R.H., and Lyle, M., 1993. Seismic stratigraphy of the Ontong Java Plateau. In Berger, W.H., Kroenke, L.W., Mayer, L.A., et al., Proc. ODP, Sci. Results, 130: College Station, TX (Ocean Drilling Program), 33-49.

Rea, D.K., Basov, I.A., Janecek, T.R., Palmer-Julson, A., et al., 1993. Proc. ODP, Init. Repts., 145: College Station, TX (Ocean Drilling Program).
Rohr, K.M.M., and Schmidt, U., 1994. Seismic structure of Middle Valley near Sites 855-858, Leg 139, Juan de Fuca Ridge. In Mottl, M.J., Davis, E.E., Fisher, A.T., and Slack, J.F. (Eds.), Proc. ODP, Sci. Results, 139: College Station, TX (Ocean Drilling Program), 3-17.

Scholl, D.V., Hein, J.R., Marlow, M., and Buffington, E.C., 1977. Meiji sediment tongue: North Pacific evidence for limited movement between the Pacific and North American plates. Geol. Soc. Am. Bull., 88:1567-1576.

Udintsev, G. (Coord.), 1982. Pacific Ocean, 1:10,000,000 Mercator. General Bathymetric Chart of the Oceans (GEBCO) 5-07 (5th ed.): Ottawa (Can. Hydrogr. Surv.).

, 1984. Pacific Ocean, 1:10,000,000 Mercator. General Bathymetric Chart of the Oceans (GEBCO) 5-02 (5th ed.): Ottawa (Can. Hydrogr. Surv.).

Date of initial receipt: 4 April 1994

Date of acceptance: 25 January 1995

Ms 145SR-136 